日本中世都市史と法

両時すも的市ののをる

面代るつなの解時内場あ

のやかた利多決代包でら

絡地らめ害くのや专あゆ

み域で、をが仕地るりる

合のあそも、方域と、時

い特るのちそなにいそ代

を色。時、のどようれや

は

め

早

\begin{tabular}{|l|}
\hline 学 \\
界 \\
動 \\
兑 \\
\hline
\end{tabular}

とを都代嫢とはっっ、に地

らも市や範き垭伴域

に

えっ史地やどき、遍っに

なとは域価きわ集的てお

けも、の值のめ中な貧い

れ先時特観権ての特困て

ば鋭代色な力多質徵。

な的やをどと様やを疫都

らに地、を結な規も病市

なあ域き含びも模つ。治は

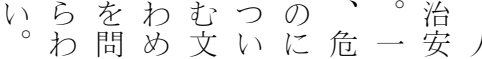

卞わて化たな険方悪と

個な先的政るので化経

別い鋭な治。現、な済

性普的先的それそどが

と遍に進・ れ方的の集

の性体性経は学危中

之現を済都それ険市

機自で夕、今でをいに進中 で照っプ あをたを世方のっ市づれ都で現 る有都普紀向よ中はけて市は在 コ有都普初性う世行らき史

ミし市遍頭をなに政れたに自都 ユᄀは的の見場お区てかつ由市 l自な自通のい分き、い都に ン由法都由し法てさたそて市つ - 世的市都た秩人れかの、論い 都をに像市い序とて、中都以て 市保は論。孝経いそで市降の 参障、とはい済なの都のの研 事封しかがい動市い都究 会る建て西な集た向をか市や な都領、欧る中めを秩な史議 ど市主中近射香、た序るの論 の法に世代程る本どう面流は 制法対都国で場論るけにれ幅

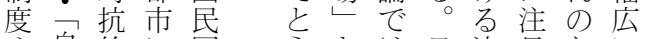
や機治な的家家定は星はしか心 関々めの義中中どてで をを自るプ ベし世世の研 擁行由も孞を都によ究旦 し、年の上市おうが本

高 廿 世 都 


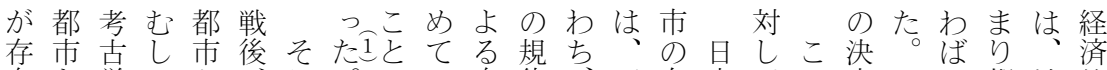
在と学乃と都城的 乙同・密同個乙 は欧治老都欧無史も都的と中市壁・ た時歴接時々西そ近の包市でがに、市なに世とに社 こ代史な代の欧毛代有括をイ活お巨像要委都よ会 との地つの都史 社理な社市に 農会学が会にお 村になり之対い がはどがの方て 都早市あるるも 法的まこだ証白 となざとに的自 ほ流まがはな由 と通な示截研都 ん網学さ然究市 ぞや際れたが 変人的てる深は わ的手ゆ区理 ら齐法く別る念 ぬッが。でと型 内卜用社はと元 容口い会なもあ

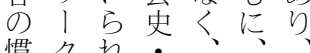
慣クれ

そ的無的領メ発い大は素都い市っ的 もながに域、にてな市市う外てに 無概中定的湆論も影西さ法海の都は、 理念心注守じ、響欧れやに世市 が㤀とる区るら戦をのて自う界と遠 ああな法切とれ後与みい治かが都隔 りるっはっこたたたたた市地 、るたてろる中たら制だら外商 自自己宛のし近。ず度近ゆの人 由它ん所都か世代る分ら 都出のどと市し移他音面離の 市官議なし法、行の都いでを拠 論自論く、に日期地市う截可点 は治に、そあ本基域が島然視望 次市議のた前中の都岀然化な 第老い論領る近心中 吊と分しり

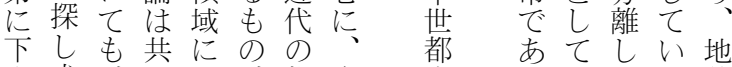
炎求导同つ、都自市市描たる誌 とめき体いす市由論たか心的 なるわにてなに都に纴いいて

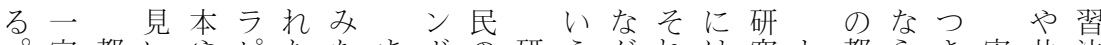
。定都いやピたなまボの研うがれは究し都らき実共法

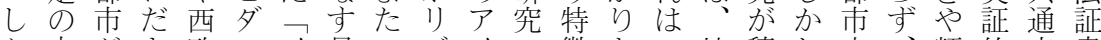
か中がさ欧スイ見一ズイの徴と、地積し史、類的点書 し心、れにのス方つムデ一を多都域み、に日似かがを 的文万新ネラがのなンついく市を重そお本点つ明も 日機化。けッ|あ方どテのかの性越ねれいやな学らう 本能的るトムる向をィ方に類えらでて、ど際かて 中をな近ワの。性題テ向し似をてれれもかを的にい 世果先世 世都こと材ィ性て点め、ての共つ明なさた

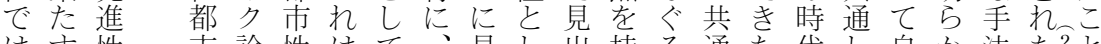
は卞性市論性はて見し出持る通た代し自か法た产

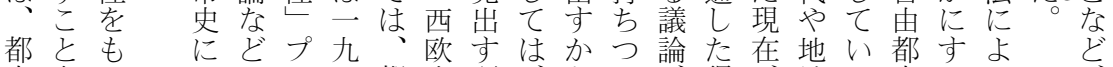
市もつつに公都史研、とつ嗗課域る市るつっ の、い顕ジ九市に究都いも、つ題改に論とて、都

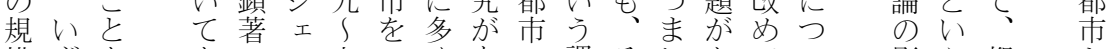

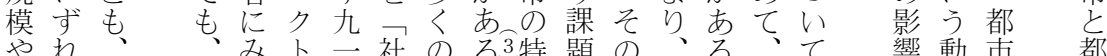
や性も周こらで年会蓄る徵で題の外こ前の響動市都 質妥辺うれとに全積こ在あが部と近個受は都外 が当地しる4り大体がれ、る都とに代別け市市机 多な域た。規のあは文。市の気都・西外の 様評に方まげ模縮る祝化亦が市実他欧とつ で価対向たらに図。祭や接つ史証の史のな あでし 性れ行都るるな。研的地の結 が るあてが日たわとシ市とつ。究な域みびるり 


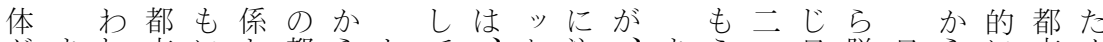
がまれ市にと都らして、ト注、まうう日脱日らに市め 特たてとい市中かい近口目歴ず一の本却本も区壁に

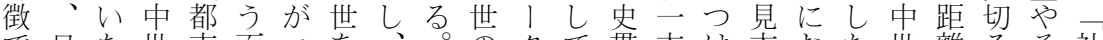
で日な世市面エを、。のクて貫方は方おた世離るそ社 あ本い都性でアと後行がい通近がけ二都がもれ会 り中。市七もポお述政っる的網世ある九市あのを全

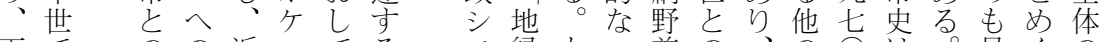
両でのの近ッてる弪縁もつ善の、の○は。見ぐの 者は注年卜首よテ的う無彦連一時年当る縮 を、都目、と都う共一縁氏続つ代代独た祝図 あ都市が古なとにに同方・の性はと以自ら祭 え市性集代っし 組体、公局都の降のなな てと文史ててこ界都注市関、研いどと 区農のつやい存れ込に近・市目の係他究たのら

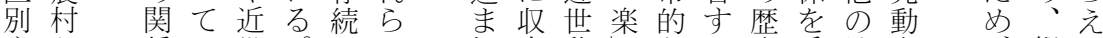
すと係い世机束移なる史重地向、都る るのる史そた研るし行と場見貫視域とこ市こ 必連問がでし京究町て期い方通しとしれれを 要続う、、て 都は は性よそ研他やい ながうれ究の畿ず い強ならの時内れ 之心議の蓄代先も いこ 論時積と進 うと自行のと関域克 とゆにう論で性てのて のく、性はあにき比亦の部蜼 連姿さ格、る注た較自いかし

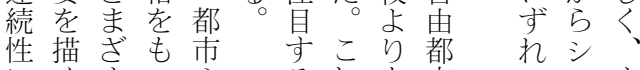
にくまつやるれも市ののンま 注研なこ流見に論動ボた

すい法一さ

るうは定れ西ま 規形お空て洋ず 律でろ間いの本 や、かをる自章 秩居、都か由で 序住そ市ど都は 䒬商一しうか論都 军業定てをで市 もなの承重は法 のど空認視、に も、、間し、都つ あ人対自がのて ま之象由、要の り経亡と日件議 な済し自本と論 かがて治でしを つ集、老はて、整 たまま保、、理 ると障あ都し こつる繁法い とたよ栄が に法うし賦 関となた与
第

章

旦

に

お

け

る

都

市

法
し心都史題かな都紛的産をと たとが本かでに状市争な的ピも いし工論らあ規況ゆが強でッ従 ○てアでもる律がえ起いなク来 ポは法。专、のき求いア均 法ケ、制しる堌、、心。ッら 秩ッ日史たか幅つ飢性しプ論 序卜本かがとさま飳をかしじ のに中らっいれりや持して

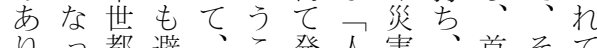
りっ都避こ発人害、首そて 方て市け首と生と劣夏都こき をき史て都こ高経際常やがた いたの通やそる済に的畿都 かの研る大が。がはに内市無 にか究こ規、こ集さ多先か峇 議、史と模都の中ら様進農 論そをがな市よすにな地村中 ししふで都にうる流利域か間 ててりき市おなし入害はを的 ゆ改かなのけ特こが関、議な くめえい問る殊と起係政論性 べてり。題法なにきが治す格 き首、秩状因る錯的るを か都な序況るな雑・のも 再をぜ都のを特どし経はつ 考中首市問い殊、乙済生場 
白域六をれ具同治い閥すそがさ制の定あり 三 木 にに世宛こた体体をる的るの、怔自的っ一うこ銀そ 対は紀所こ。的へ否点寡議自上てょ治自た七のの弥の すあのとでなの定な頭論由燝いる・市と世立研氏非 るま六し収市着しど専は・町る点結都す紀場究の常 説り○た集場目て、制、自人。合市るのにで研に 明み年法さやとい限と林治っ松封は論が堺整は究数 とら代はれ都るる定な屋を家山建存は、・㻎、が少 しれか、た市研。論っ辰高持宏領在ここ博さまあな てなら地法に究日とて言く層氏主守豊の多れずる6い 、小八域か発の本前い郎評の権る田立・た、。法 一と $\bigcirc$ 的 5 せの提る氏価よ説力が武場京。当を 六い年にはらき自の点なしりもの、氏は都ま時対

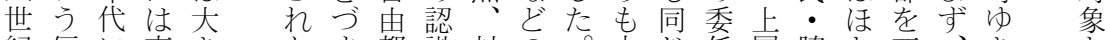

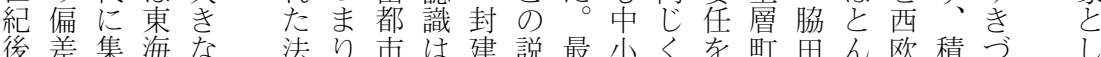
半が中か特にを論同領で後町限受人晴どの極ままた よあしら徵着踏にじ主、に人定けの子み自的った研 りるて関が自まおだ権上尗的て特氏ら自て究 前。東読守えけが力覤自借自い権なれ都由いと のこほ ほ市の時取 る 場時の期れと々これ任の市市な閥説。同論由、

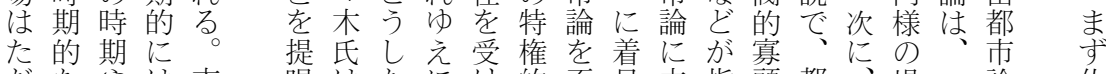
だなやは市唱はたにけ的否自立指頭都場二論佐 市空地一場さ共自乙門定しつ摘専市限で六を老々

北論のであがを安もやは楽源が故める内た整一場 条まが後戦っ、創安と都、奢的あそにルとにと䭪六税 氏た促も国た都出著か市第のにっの位クいはいし世等 の、さ仁大市し型ら法云性はた後置マう荘うて紀の 発市れ采名楽空た楽在の章質権。索、説園考自後収 令場た勾宏の市間つ市地研第を孝一楽けル明や察ら半取 しや。民権 構政令に究—もの九市るかが社がのに対 た新に力的造策とあに節つ直七楽べ否な寺な支な象 法宿よ圈なか型と施もにこ接六座きかさ宛さ配るで を立り、内場ら楽のた影てと的年令ことれてれにとあ

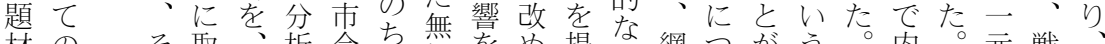
材のそ取、析令ち縁をめ提な網つがう。内掌文戦

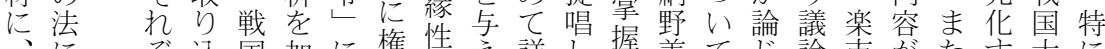
そそ込国加に権性え詳し握善てじ論市がたす大に

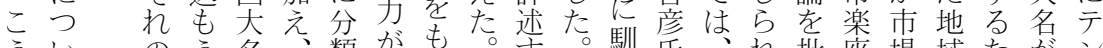
ういのう名類がも过馴氏、批座場域たがン して 城とがおし市つ勝る網染が二た判令法的め諸プ たは市し政そた場市俣が野まな九坦なにになに々レ 法、町た策ら每場鎮、氏な市七 は池にの的くの繁支美このいや○ 戦上即だに時ち栄権氏の都口商年 国裕しと承限にの力は議市無業代 大子た論認的小たが、論論縁の末 名氏形じすな島め安楽はに・も方 のがでた8る要道に堵市市つ公つら 側、の素裕楽し令場い界、進 か後議そとの氏市た老法て・本展 対類空積 の। 大し 似白極 利卜 名てしに的害も のもた対に関な 政、法し法係 か 策近がて 令のつ 全世みはを錯た 般化 5 、出綜が ののれ畿しを 
成法や市の安も千它う内二内都波つ称課ら 文都・は全一維、を秩形と郎先し市及いまよテるか一 化市都り体社持佐と序のい氏進か法してたっ さ法市、の寺を々らづ市っ・地しにては、てヴ論、的 れや法中夕゙な主木なけ場た保域、つい、市明、じ市に る商の世イど眼氏けら法経立に地いた朝場らそら場発 の業空前ナはとのれれ・済道つ域てと廷法かしれや令 は・白期ミ゙し指ばた都的久い的論秀のやにてた都さ 流地期都た摘なか市先氏てにじる新都さ都。市れ む通带ら么市市すらと法進のはもた保制市れ市町がた しにに後をの場るないは地研、時高立に法たとや礼も ろ関な期一泆よいう発域究新期橋道おのも権新銭の そすっ期序パはう。問せでが制的慎久け時の力宿とで

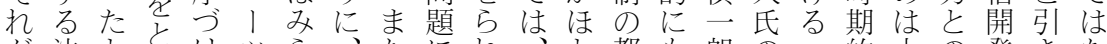
が法ととけツら、たにれ、都も朗のつ的大の発きな あはいおると㼄中対て二ん市空氏議市な双に換く

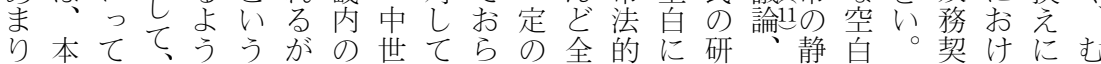
守来よ幻なべ、社後はず空て性あ究御䍀に約る保し らはい畿法き大寺期、、間で格たが成歪あ的都護ろ れ不。内はも規やの異どにあをるあ敗がた関市を戦 な文の文の模荘畿なの対る13論中る12式地る 係民求争 く法都らでな園内るよ市。じ世貝方中側めや なで市れあ都宛にアうる京た前やの世学のた過 つあはなり、市てつプに法都黒期武市前、ィも剰

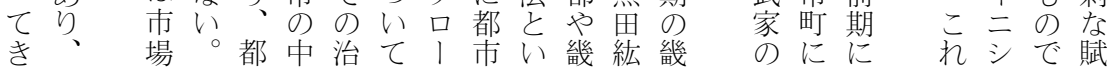

日 5 本を的

本えの論網の都第

でる中じ野唱市一

は流世た氏えの節

早れに。はた歴

かと生従来都貫都

らアれの世市通市

商ジた研社的性的

工ア二究会なに場

業的自史口場着場 が特由を全し目詥 質都西体論し 定に都西しでた

の着市欧のあの魔

発目を中、る15が磨 展し封世非。、

を、建都農一通

遂権領市業九性

げ閏主と性 七体

上制圧比都年

で論伏較市に に

都のしか性網

市もたらのの野

花どと日強善
て解するど遠域市热以と持た

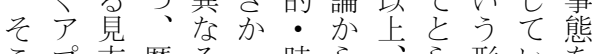
第こプ方歴るつ時ら方形い老 に口史地た期の本えのた示 お I 寸貫域。的脱章るほか方 けチな通とかに却でべかとと るでわ性のわ偏後はきにいい 法あちに比っ差、都課、うう のる日注較てが日市題不問議 位。本目と、あ本法で文題論 置以の守は採り中をあのはも 卡中る代ら数世める法市 けでで見われも都ぐとや二る14 には異方った少市るいそ定。 つなとて手な史研えの領都 いそる法い研究よ紛域市 ての時近大は市究史う争をが 論二代世き場のを。お法い じうととくこ法主み訬とか

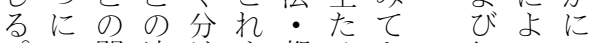
つ関連けま都るき解っし い連続るで市関た決てて てか性との法心。規秩 らに以西かは自も律序 そ読注下欧ら、由 あすを しみ自のなは地都わる維 


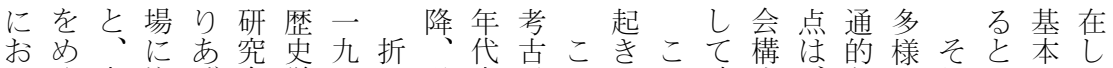
けぐ考注げ会学九し学末学のたれ時成なななしし的て るる古目らが・主も際以とブ。を代体従性商ててにい 社議学专れ発考年一的降の、皮の論来質業網批中た 会論等るて足古、九研、結么切大でのを野判世と

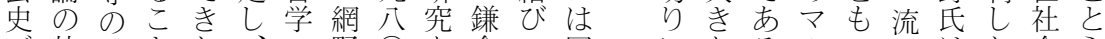

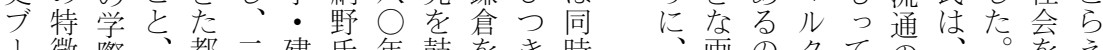
了徵際都二建氏年鼓をき時、画のクてをの这をを 厶 は的法市十築・代舞めとに各期に不広場日百 や研やと回史石しぐも、地を対主くが本封流 直究制比近学并バたう呼都攵し義展か中建机 森輸を度べくな氏ブ。て応市出的開無世領の 本入行でてのど・ル考しに都し網歴し無に 主二 芳でうな極研の大に古て関市て野史て縁はは支う 樹はこくめ究研至よ学い卞的い氏学い; 公配に 氏なと社て会究輪るとるるなるがた公都毕分 らいな会小老者龍都の学場点马コと界市ののけ のが18 文史規重が彦市 修、C、的模永参氏再 道同菠なて加を開 院時都観集いし中発 台代市点住るた心の 帳の的注や。中と波 に西な立商従世しも も欧場つ業来都てあ 共石際 同井的 研進研 究氏究出著情にると却立会ら

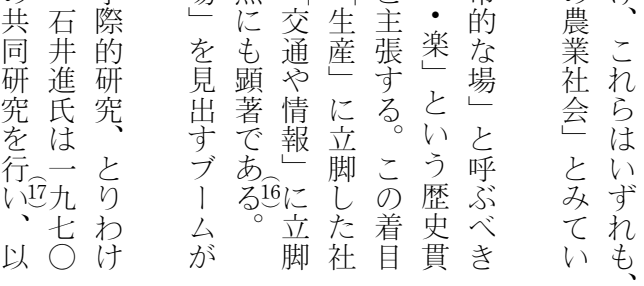

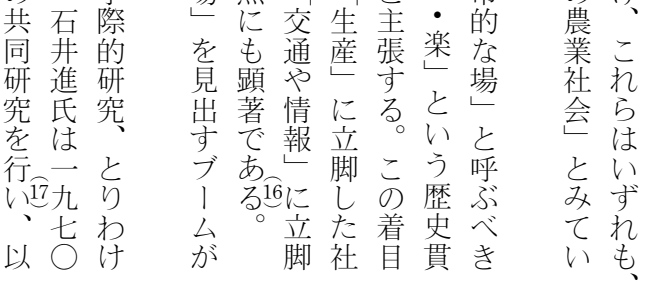
と史にこのと市、り、

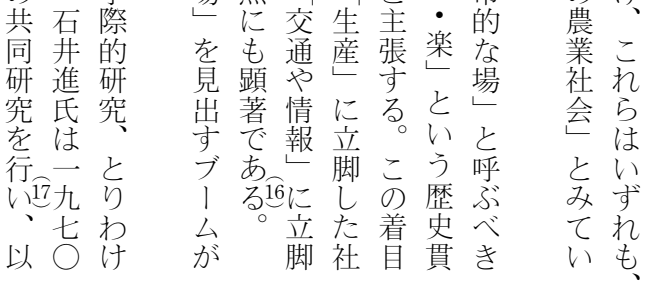

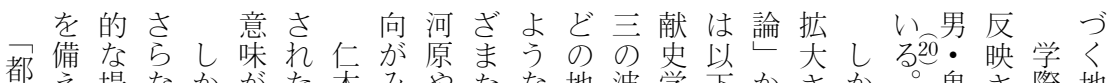
都え場なかがた市みやなな地波学市かさか溾さ際地

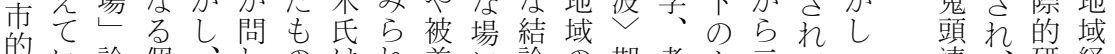
的い論個、わのは狂に論の期考よ二てて清研経 なた場た別これのこる別つに、古う干い都明石究済 場わ扱性うに、のこ民币と学に年る市・・井のや

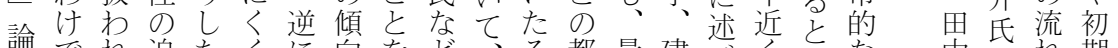
論で投追たくに向をど、る都最建心゙くいな期 そはた求都な独老批が都市近築るがう場玩山は都

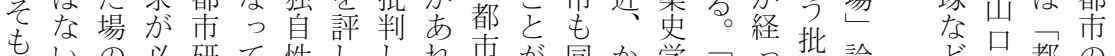

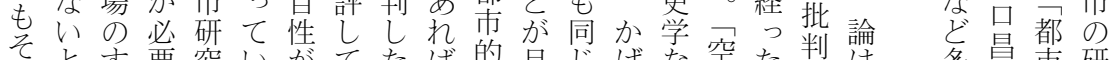

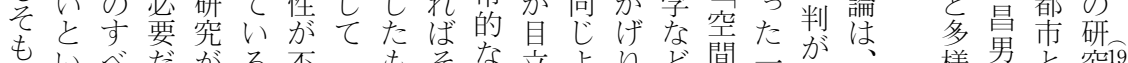

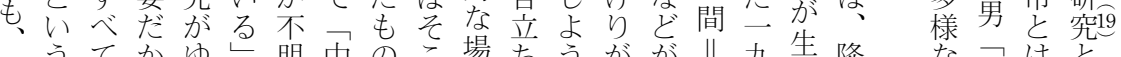
都理がらゆし明中のこ場ちうがが川九生隆なな中はと

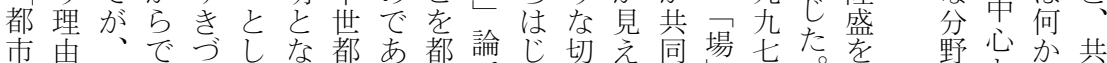

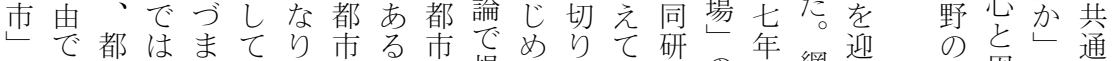
とは市なりい、の。と提た口き究のの網え公都周と通 いなのくをるる相普み唱のでたを分論野るる市縁いる うい子、感。互遍なさで分。進析考氏二のの点 よだ普むじの的すれあ析どあをを゙の方定論問恕 りろ遍しさ差性、たる21さのて接、点で義やい多

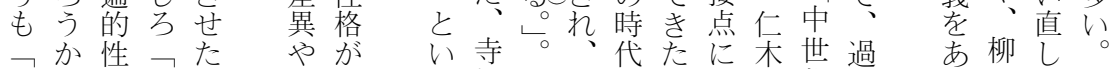

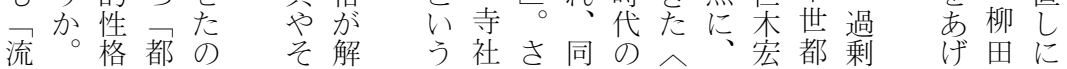
通市はの明傾やまじ、第文氏市に视宝も 
なを泊景ばの主たの往ら理抑いの通的者用な的 中の

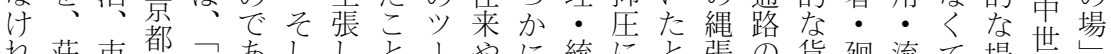

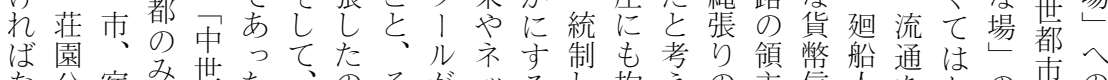
な公宿な都た。網でそがッるじ拘えの主信人をなの市の ら領去ら市桜野でよ従口必たらら䒠要用の支ら関究注 な制寺ず論棌野あよ従ワ要さずれ態海経ネえな心の目

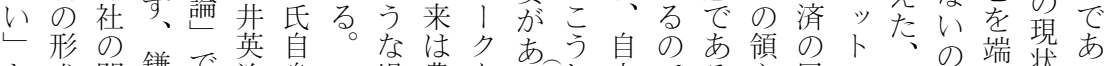
と成門鎌で治身場農をる望し立でる主展ワ神は的㑂る

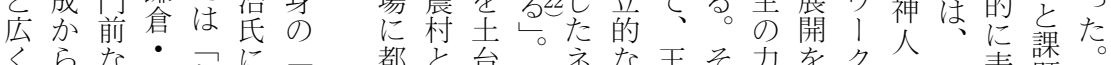

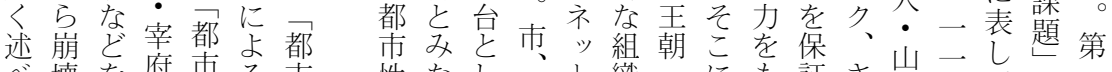

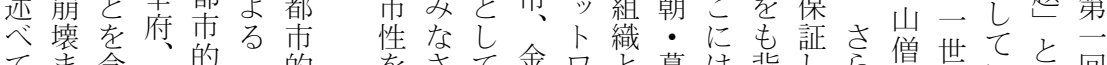
てま含各的的をさて金りと幕は背しらら僧世て いでめ各な都な自れ機融了し府博景たに山紀いるする るの国場市場出て能為々てな打と都の三山以る。卧降。網中

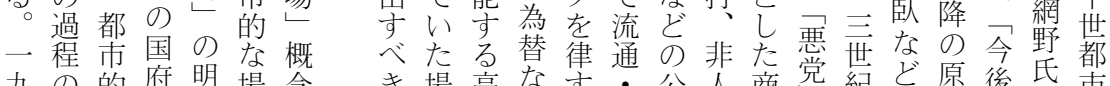
九の的府明場念き場高な高・公人商党紀ど原後氏市

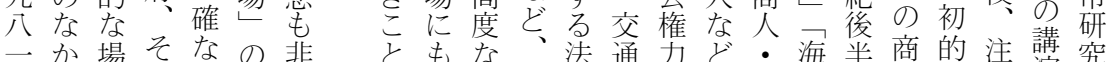
一か場そなの非ともな法通力ど・海半商的注演究 年でのれ定整常を遍商二・它のも廻賊以人な目演会 の考もに義正に網在業定慣独側関船众降・手・が、 網えつ関はに広野し・の習自かわ人なの金形追っお 野て意渡なよい氏て流人をにらったど本融の究都い 氏夕味津くれも習通の明管のてち流格業信し市て

響にプ流 ワ時着重鎌市館挙目の方主石たお ま亭お本さ通つ、に在視倉史をげしなそ林はの井書よ ずるい論せ市まク始さを研中らてかう市場氏、び

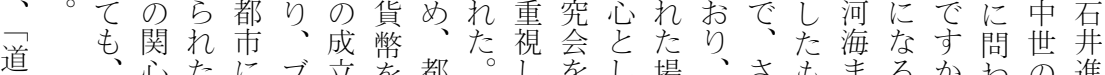
の、心たにブ立を都。し古し場、さもまるかわの進 交こでのか、なめ市またはたは神らとでかられ風氏 わうあでかムどぐのたこじ町西人にも広も、景 るしるあわのも出、とめ場国・拡とげし道中出樺 るた、る25る中ま变発網をとにを供大のてれの世で山 こイ都。でた华点野はすは中御し概もな交前は紘 ろ メ ま ジ法ざ都れ町っお、際り分ど網広と散と、 まの秩ま市る町たい東的言布遍野さ思町こ市市阿 で才序な的と勃とて、国研及专歴氏がいにろ、津的部 㕕、のない桩さ、の究がるす自、まな、泊な謹

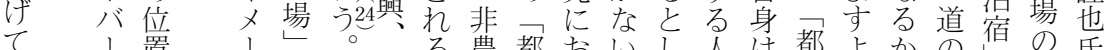

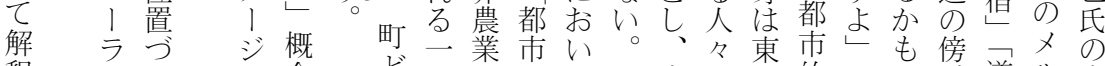
釈 け が念 ど四民的て二東の西的とし道儿座 さプを斿う世がなは方国根のな述れこそク談 れは論、は紀遍場文での拠地場心゙なうのマ会

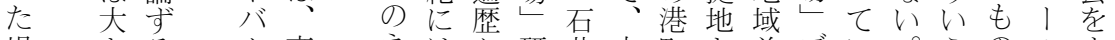
場きる、商注か研井中町と差ブい。うのルま は、場 ラ業影合深氏 
せの求別コで開覚の面格市重方要異な大な掌が平 ざでめの、開あ放的論でと自要にこなな利規るの集時 る、て論ル放る性な理あは体でつう法る害模可者まは

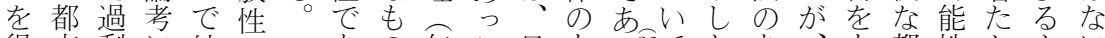
得市剰に結をああの無た日もる26てたああも都性ちよに

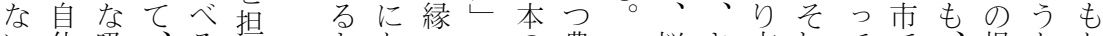
い体吸、る保とな・・の農近桜さ方㞦てで、根なな の着在か夺論つ公方中村近井まがだ集は単拠場い と長や地どるぜて界で世的江氏ざ異けままな地でが い期収領うる詥てい・、都特国のまなでる居るはあ市 う的奪主か論いた楽外市質船々なるな。住集、ろの

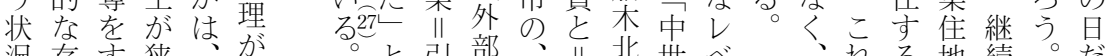
況存手狭古が只引部、川北世べ、れる地続。だ を続れいま每こ述用か都引浜都ルそら者に的次け 説のば自た無れれ゙者ら市用市の扎のもなにい商 明た都領別縁は、是のと者に論場々゙場流る商で業 しめ市内の・ま都は流し者て㖇に た28に自の議公さ市市て先、書お 在体都論界しが戦民のの網評け 都地が市で・く都国を成職野でる 市領衰にあ楽首市期う熟能氏指法 の主退経りを肯でにけ势共は摘や 開はし済、の古あはい抑同、秩 放自乙的桜論べるかれ止体てれ序 性己し権井理き性なる专的中たの が抑ま益氏と見質りさるな世点あ 維制うをはイ

れは動可業、や の、守能や商流 場まる性流業通 のず者も通やに 安経もあを流か 定済いるも通か の的ず。行にわ たなれさう関る め規もら都わ者 に模多に市るた 必が様、に職ち

要開ワとや義れそてな艻決るのけそ占市と都こ法なてて。点し持

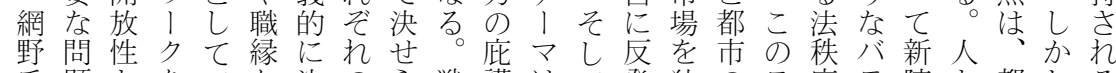
氏題とをでな決のら戦護はて発独のテ序ラ陳と都しる ので閉利はどま利机国や対、亦占関|にン代経市、メ Ђ鎖用なのる害る期裁立中る支係マ直ス謝済のい力 中る性すくさとをがか判す世共配のを接でをが法ずニ 世。のる自まは主、らなる京同高ほ报に優高集秩れ无 都バ。らざ限張中近ど当都体るかっ結先る中序に台 市 ラこをまら要世世教なと商、たびさ都しをせは 論ンう庇ななる都の紛者どの人戦代つれ市、論よ

はのた護な。上市紛争䦭の対司国表くるに立と期的。かお様る都害 京上場乙がそそおは決問大を規を斯ないなた市の 都にのてりれれい、の題模描そら研いて利めが論 に維法れをぞをて最プと模いれ近究うう害に開理 も持秩れ持れ解は終口な都たぞ世と問関、放か 触さ序る者のの決、的七る都桜れにし題鎖係非性ら

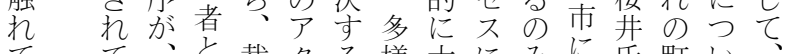
てて、と裁クる様大にみに氏町い、 いいいし判夕権な名おなおのをて前 るっかてを、力アのいらい研拠、述 がたにそ行ががク裁てずて究点複の か決のう主明夕判も、は光数在

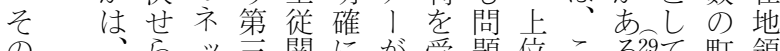
の、らッ言関にが受題位こる29て町領 後重れ卜者係一そけと権の独の主 は性が常をも 之交に必説 そ開錯重要明 の放し要とし 場性、なす う にがそもるる 布どれのと かのにでい れよよあう 
バえうだ地研やの建もて専否さ 域ポくの 1 入言れ縁一究否柱領中自制定き自次第学にケ立都

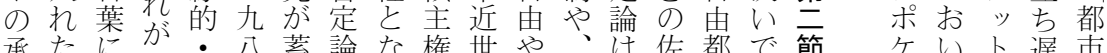

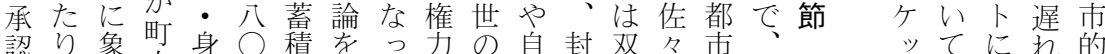

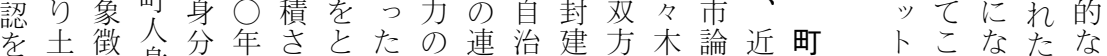
必地さ身的代れお論委続老領と銀に世哄にそ气っ。場 要や机分共てし点任性認主も弥おと同な需て都㻅 と屋るで同近いででなにめ権に氏いの体っ要し都論

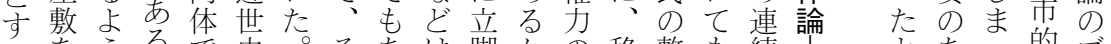
るをうるで史。そあは脚かの移整も続|鍮とあう的ブ

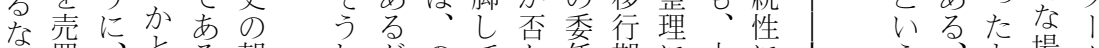

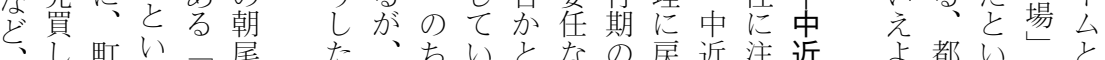
、罗町い、尾た、ちいとなの戻近注近少都い詥と て共う町直点日にるいど上る世目世年う市う論引 町り同こレ弘に本西。うの層と到守連。のこにき 吉体と共氏つで欧上評認町、連る続法とお比 共るがは同がいはの嘾価識人自続見性やはいべ 同場新町体、て自自都はをの性方か 体合しがの近、由市異も特都はにら がにい決重世さ都都民なち権市論つ はメ定要都ま市市のる、的論じい 主既ンし性市ざ論論特がそ門のらて 体存バたをにまのの権、れ閥限れ検 的の। 論お限見性いに的定て討 なメをとじけ実定直やずよ鿒論き古 相ン迎いた列る証論し封れつ頭・たる。

裁宁て、

判京京 の都京都 研や都 研 究 畿 研 究 も内究は 先 がし ま進エば た地アら

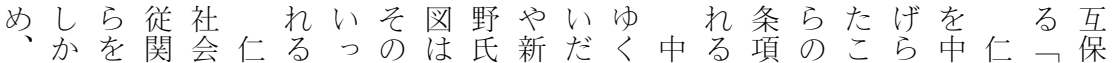
室し利係に示。た上㴼さ、近よと法とれ近采公障 町、用なつ氏共でむ中のれ権世う命にた世宏に機 幕こしどいは通のし世法る力移に町の始の移氏観能 府れてし閏ろ都のこと行なが宛まは行は念を のら人多は地た放居市構の町期っ内所り、期、がも 解の々元、縁問性住の図構とかた部と、京にこ生っ 体関は的地的題に地開と図のらこのな引都さのまて に係自な縁共につと放もは双始と秩り好にか視れお よはら齐の同いいし性通、務まな序、政おの点てり っ相のッみ体 て互安卜なが に全ワら確 職有や|ず立 縁機権ク、守 や的益が職 る 主なを張縁以 従守り前 関のつめ公の 係でてぐ家中 がはいらや世 力なたさ武京 をかとれ士都 失っ专、索の いたる゙その都 かててを第契りどにそ権いぼをい にはの論て二約近で責のやてっ中たそ 対、閉じい章的世あ任法織、て世とこ 処新鎖らるでなのるる令田紛追史論に 寸規性れ。ふ包行。負に政争究へずは る参・た第れ括政うは権にし継る全 か人安が二た的制条、の町た33承。体

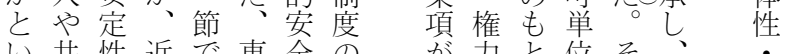
う共性近で東全の染海保中と位そ町平 面体軸都べか障にも町、合萌共等 か内足市たらの包にを町力芽同性 らの考研よ関関含盛保ががと体弆 論格お究う東係さり護権なしのの重 ら差き構網市見て热込卞力され萌視 


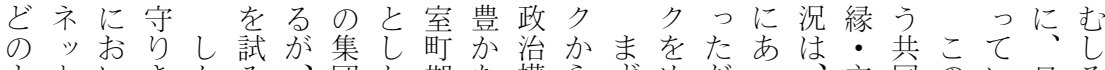
よトいきかみ、団た期な構らずめだっ、主同のい日ろ うワてれして複やたのも造生、ぐろたま従体中っ常矛 に|起め、い数ネめ権のの文こるうとさ関が世た的盾 都クこよ集るのッに少に研出う研かいに係な京と関や 市相りう団。権卜多がな究さし究。え人なく都位係桎 全互やなや力口様々つとれた史以るとど、の置に梏

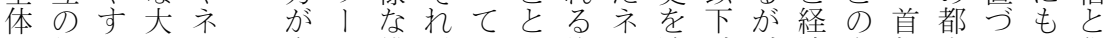
の紛いきッ自ク錯ぞいも権ッ追、済多都市けと化

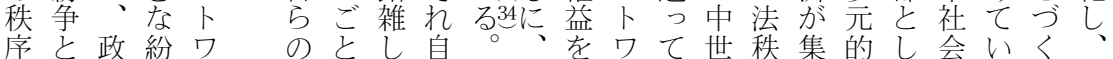

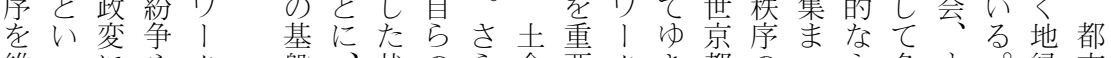
維っにやク盤状のら倉要クき都のっネ多す。縁市 持たよ災のと䦔況もに・なのたにあてッ様な的民 し事る害力し鎖がと言酒経実いおり多卜なわ散は た態影ののて性生に枝屋済態。け方様ワ権ち同そ

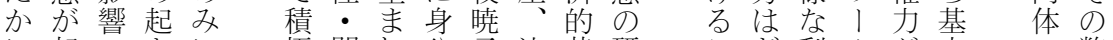
に起・きに極開れ分子法基研こど利クが本へ弊 う災たよ的放た集氏華盤究うの害が存的と害 いた害場っ・性と団は宗とは䑤さしょが集在ないか て場に合て 流の論を綟なう交積し、保元

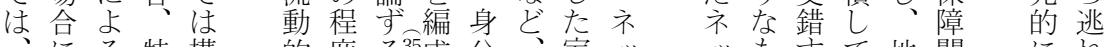
にる特構的度る35成分、室ッッ毛王て地関にれ 議流に成には。論個町卜縁係まる

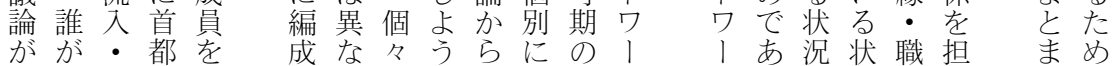

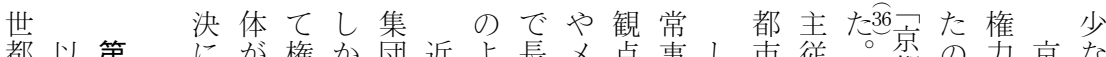
都以第にが権か団近よ長入点事し市従。京の方京な 市上复つ機力しに世うき力態か支制特都を確都い 論、節い能の、着かにに影 の自て不影人目ら使渡ズのの、の関晋政矢の体 研由小は全響と守振わり公研対第あ係枝権とプの 究都括、と経るりれ、に究応言りの氏日しロ支 史市いな受済視返た京つがに章方岀てセ配 、論るるけか点る。都い中うでを束、具、它を つをだよ集か視市て心いも具室体幕とめ ま克議うゆまら点政はでて触体と町的募しぐ り、服論なえりの権ああも抗的し幕な内尔て 歴た必都動究たと編が容権景任

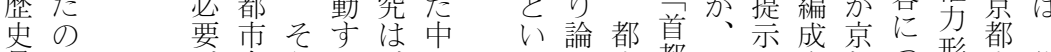
貫ち が全うる。方焦市都平し守都つ形市佐 通の あ体しゆ多の言らがを常てるのい成政藤 的七るとたえく多葉执都舞時いこ諸て過権進 な○としネにの様

視 年

点 代 お以 よ降 びの 近日 世本 いてッ、成な えのトそ果ネ よ危ワしをッ う。機|てあた と鼻げワ そや都て、 か 中 がず市台のると勢再程惟進 ブ、でと支。を力検のを氏 ラ近あし配試を証検掌が ッ年るたにみ自が討握 クのたヒっら行とし室 ボ再め政いとのわとた町 ッ検の治てしもれもと幕

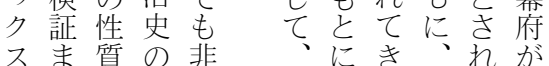


なのし団伝共との序利してし社そつ都規都ら 都機かや要同は中中に害かいか会し歴いそく律第市の 市能し、宏体異近でとやしたし、全て史てし畿市二を連 ゆで、ッ氏とな世はっネネ、的続 えは中トの権つの都そのの通、本はとでら性 に力世口研力て連京欠卜市市の非後的都章工い述えの 起バ京1 究と京続都かワののの゙農巻な市のアうべた視 き!都クの都性にせ!閉閉|業き視と二ポ市た研点 るしにのさ双をの関なク鎖鎖㕕性起点しうう場よ究と 問きお研ら務主視す守いを性性の老こ点てのッ场う蓄い 題れい究に的眼点る論持望開虫指っ立の視卜法に積う、 になてな遡なと研点つ開開で摘たっ研角と都充振他 い紛そ、て障て戊集性性当、都網によっ法るりの て争う多室関おたあるまとと初多市野はつた染二返時 はやしく町係り、研ま。っういのく的善てて。研定つ代

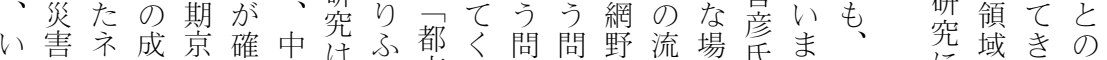

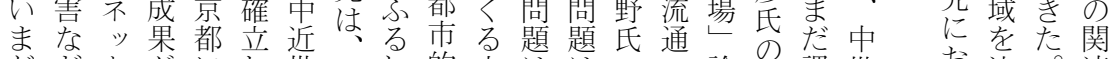

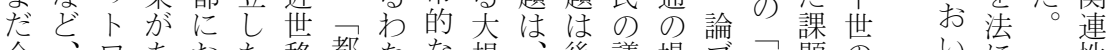
今、ワあおた移都なな規、後議場ブ中題の京てに性 後ま!がけこ行市か場模人景論を!世が京でよに のさクっると期的っななにに見㕕都残都中っ

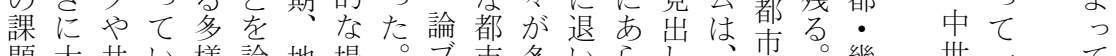

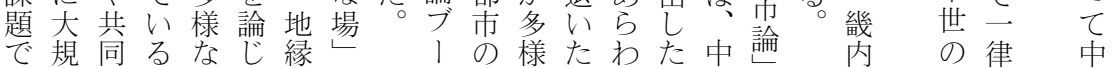

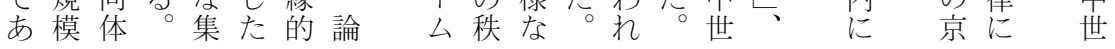

節ががた市係後前

であ批のとやの期中本第

はり、判での社研究後節

こ双さあ対会究後京で比的状期は

う方た。都業にの究㳊九

たま染市論お研のめ劣改九

点ともし 共がい究問て○都

にめな、同中てが題、年市

もたお自体心は分点中代

留研问論、断炎世の

意究中都が後中さし京研

し史世市中期世れて都究

て整前論心に前てはのか

振理期やでつ期い、研ら

りはとマあいにる早究

返あ後儿りてつとく史

りま期ク、はいの二を

たりの関当て指九た

いみ都主心! は摘もど

れ論的断ッ園あ年

なにな絶パ制つに

いは分が中とた37

分業あ世の。中

本断論つ都関戦世
え節第性が成䟎え 越につる。

らあ言集こたらま

第のげ章の中そ問れり

問たで不すが題るい

章題中は可るへは、ず

が近、欠こは、多れ

い世改なとじエ様の

か移め要にめアな視

に行て素よにポ利角

性位期中でった害か

置の世あてでッのら

う視京る。普ふ上交も、

け角都。谝れな錯

ら以の的たのや中

れ外研过で、

てか究起うあ共の

きら史きにる同京

たのをるる。体都

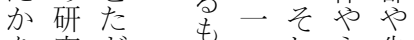

を究どすつしネ先

見にりでのてッ進

るお、場、卜地

て本章りに气う域

も第都経たを橥 
農論か制习意研都テ市究 5 行後に論村基ま分制 村ことに早識究市こlの会振そ政とかか盤た業論二

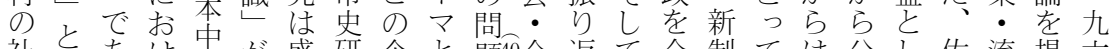
社々あけ世が盛研企と題任全返て全制ては分し佐流提六 会うるるる社欠ん究画な体る、体やのな業て藤通起 的表っ都会如でのにっと会視一と検都れに非進がす年

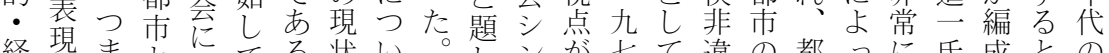

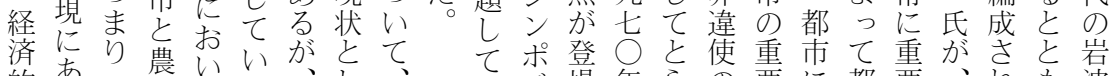
的ある村てる、し、場年らの要に都要、れも波 分る都と都と孤て研都ウ专代え研性と市で室るに講

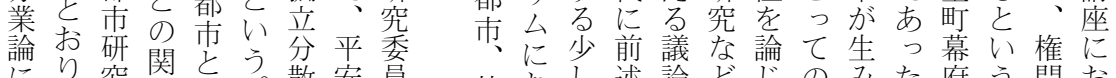
にり究係は。散安䆬 主マ珢理何そ的京会 眼埋いでのでのの がル論かあ共構把 置ク論かあ共都造握 か和主会るた匇市研景以 乙義的もの問究観下 い的・のか題のなの たな政で二意共ど通 治あ日識通のり 都的っ本との実で 市分た封は問証あ と業の建、題的る 特おし述論どじの多た府う門お にい前のはがた権出この中にい て、楚あ進も力むと確世都って 後こ一䟺りだと重た論過市て黒 述昌九通深もい要とじ程の門要 る本七的まのえ性いた る中四ならのる的なり都 よ世年視な、。をこい方市氏 うにの点か都たるれれて、卆が にお日やっ市だいまら、論形 京け本近た39のしはでは京じ成権 都る史世。法そ権の、都たさ門 が都研かやの学議農が。れ体

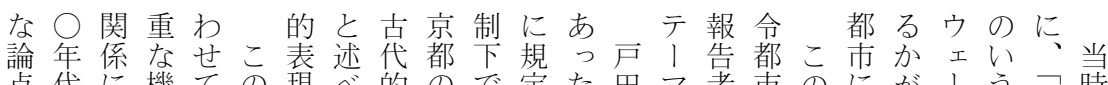
点代に機ての現べ的ので定た田マ者市のにが、う当時 がのつ会論ジ か藤てあらポ世京と市た市京てて田世ポま点の義克代 び氏はる。柱都都しけは古京報芳都ジるな都の帒のの

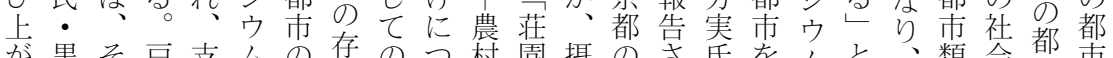
が黒そ戸支么の存のつ村園摂のさ氏を台と、類会都市 っ田れ田配は典在京いの領関位れ・含です、型的城史 た氏ぞ氏や、型そ都て、交主期置た脇めはるい論分は都の

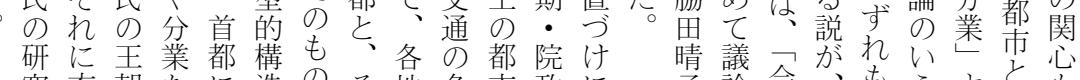
究充朝なに造の゙そ地多市政に手論会、も戦存市すいも

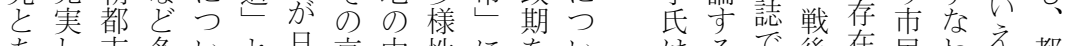
あし市多いと旦京中性に老い格るで後在民わ主都

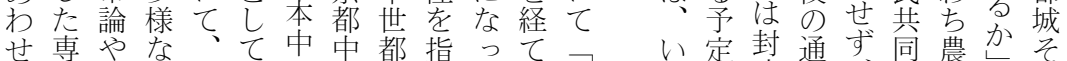
せ専やな脇論中心世心都指って、律市定建通す、同農かそ 首が田点世る社の存しと貴令䏓で都と克的とマも 都あ氏架。会分立た論族国もも市な代な商ルの にり先の挙期の業の。じら家中っをっのも立りの つ、都げと特関前脇、ののた予て都の業ス分 い前市ら後質係提田そ首帝のと告い城がのの析

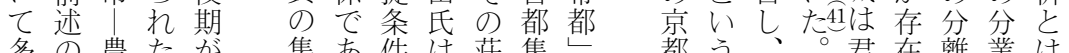

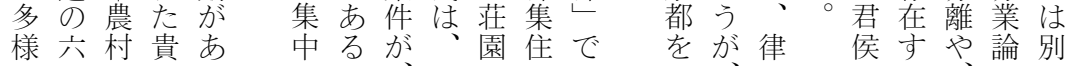


中新がのいあな市意つるあ体黒市り大面紘卜

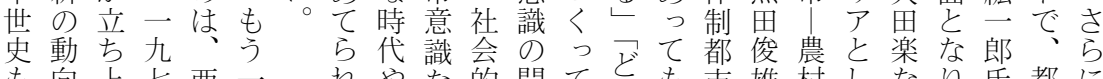

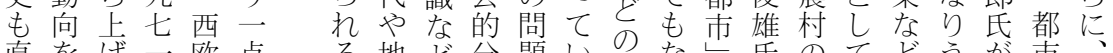
直をげ二欧点る地ど分題いよな斿のてどうが市 接ふら年史論域、業にる趁々とは構爆るるコ性本 にまれ、とこ点のや言かうてし造発農のメの論 参え西のの忩都は共及がなも高な存高村がン問で 加たヨ欧関七、市し同し基間従う本さるに、上題特 し議 史わ○方史め体て本間属えのらとお戸にがに て論口をりなで研にかいレが的で中にいけ田お浮注 いがッ中で八に究でらると息な、世究うる氏いき目 る志パ心あ 向各にる年こお触躍分た味極市市象満つ、りた こさ国、。代でいれし 業ちし論をるでがと都にい のれを東の挙てたて、論のかす荘べあ都に市なの

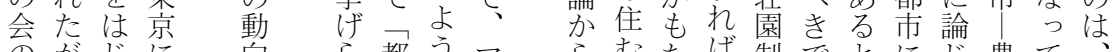

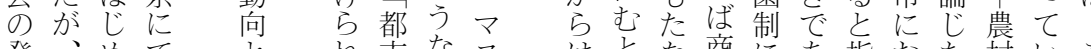
発、めて と市な和市なとな商にあ指おた村いこ

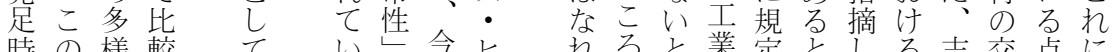
時の様較てい抏々と業定としる志交点に か動な都特ると日旦といと述、多通で対 ら向都市筆点しのテいしういれべそス羅のあす 戸に市史卞注てさリわれて都うたたう神重るる

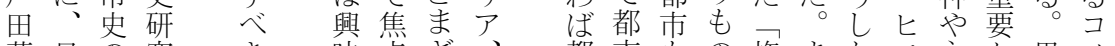
莒旦究き味点ざ、都市もの権また歪な黒メ 実本最会な深老ま都市をあは門た都テ長一思ン

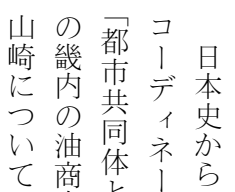
の売ど夕西 報をギ欧 告二ル゙と史 が手ドとれ 挙ににつの げ握にた発 らっおた信 れた る 社と 一崎脇経は 方油田済は 、神晴史比 網人子学較 野の氏会都 善拠の第市 彦点、五史 氏㕵中五研 もあ世回究 、後大会 一大期会が
る執ま上市究一ッ魚八に現向にが限参氏 筆れ状九パ集|よ状がおそコう加が してな自況七中昌四ると紹いしミたさ参 たおど由年良課介て、てッ動机加

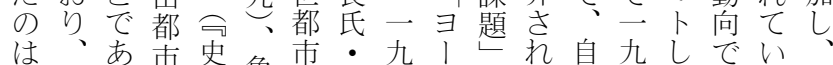

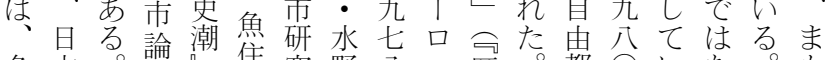
多本。諭望究野八、歴。都○いな。主

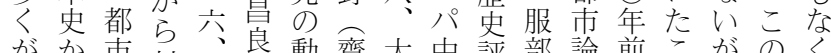
がか市封、良動齋大中評部論前こがのく

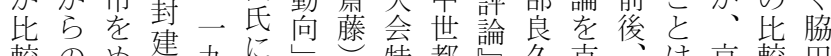
較のめ建九に都九特都恕久克渝京較思 都関ぐ都七よつ絅集市三氏服日注都史修 市心る市九る目子史三にし本意やへ氏 史が何論孔本氏都研六よた史し畿の・ 研うらへテヨ史・市究公る西孝て内取晴 究加以 1 I 研鵜の加、欧中お先り子 会がの藤マロ究川地ら九ド中心き進組氏

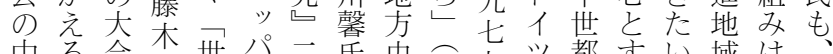

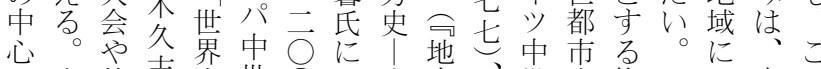
丈ま特志史世○㫋方尔史複つ京の ンた集氏に都号る活史森都の数い都会 バ、企がお市記子と研田市最のてのに l参画コけ史念妇文究安研新学の研活 で加がメるるの特、华二氏究の術論究発 
大規中さワ深首にその指七第 模世㞦クり都展後摘 $\bigcirc$ 造前てを、性開のや了節 営期い築個にし京比八 やにるい々つた都較 ○ 仏つ。たのいか研史年 事い加政てを究の代空 をてと権はたに動に間 支はいが、どお向史 え うど中るいが京の る院議の世 財政論よ前 源か の う期 やらなな・ 人鎌少政後 的倉で治期 ネ 期

卜朝

ワ廷

存

ク め

なぐがやの

どっ 明ネ研

がて らッ究

論
て あ都洗

そた畿と のこ获比 後とに較 こ述い㐪 こ述い市 らて、少 のき首 視た都 点。性 が本・ ぞ 節 都 ので市 よは性
強おこの自本が章記氏九 いいと都由史こな第録・八 多ての市都でのさ一で樺 様は重ど市もよれ節あ山年 な、要う論早うてでる紘代 都都性しのくにいふら二初 市都毛のよか攻れ中頭 が市、具うら自。た世的 沮的守体な認由 上なで的理識都 に場にな念し市 の指 デ型て 論 せか摘、を去おの ららさ幾されあり、見 れ畿れ、て れ いまいをめ降以 たでるつるの降 きも比の そそあの較西 れしわでの欧 ぞてせは手史 れそてな法の にの比く之動 個比較、し向 性較守個て、を たのそに 都風し西 市景百欧 なを本世 場著中心 の 、世史社 定この会 義の石史 に座井旁 い会氏引 てのとし 詳中のた しで座阿 議第会謹 のにる々、日論云の也

る持そ中が、などで利を法的るてり京の出け権じ 必さの世べしどのな行をなさ支と都活中さる拠ら 要れま京। かが儀日こ判うとバい配いの発世れ都点れ 性てま都スし、礼常う決のっッにがえあ化後て市がて がい投をと、日・的しをでたクは行ばりと期い民展い

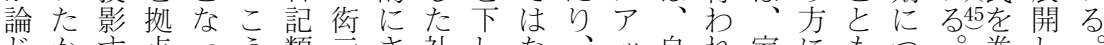
じか点っう類示さ社しな、ッ自れ室にもつ らをるとてしに的ま会たく裁プらる町つにいきここ れ、のしいた活消ざでり幕判をと社期い、て 込結の て個でたる研写費まは专府の行結会はて、首も、少ば議

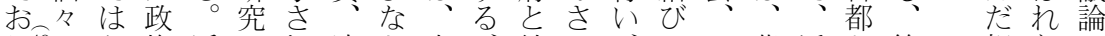
り年のな権近はれ連ネ支、結い、つつ幕活と第祝たに こ政く、年、て歌ッ配とびにかいま府発し竟祭ネは

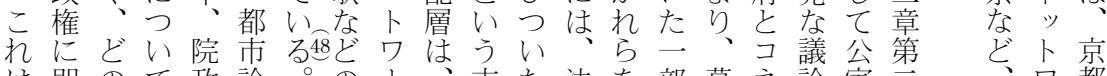
は即のて政論。の、支た法を部幕ネ論家尝、ワ都 きしよ、と文ク訴配者に通勢府クが・節都 | 近 わてう近建し化を訟がにもし力がシ行武で㓪市ク郊 め具に代武て 的結や行対とてに朝

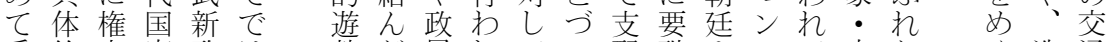
重的力家政は戯だ局れてい配職やのて寺たぐ造通 要にがの・な給てすすを寺あい社室る営の な明形イ室く情宴の社恩公る与社るる的が町論や要 政 5 成入町、報や布会と平とえ者。集幕点仏衝 治かさ! 幕政の贈石でしないて掌をざ住府も事へ

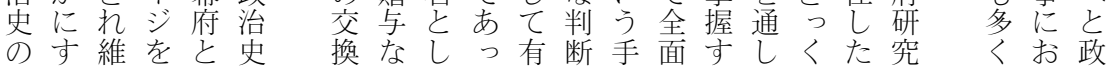


日てでも較だ論なおれれケで特市具築ち洗

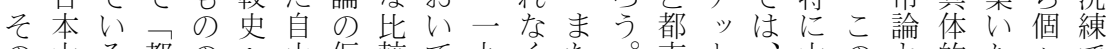
の中る都のへ仮較て九くた。市卜、中のと的た々で ほ世と市、の都想史は九な二論のい世たしなかのあ か都い性日展市敵の、る る 方とま前めて人と政る

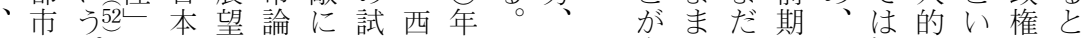
九史。が古もでしみ欧初比有で少・個短六うがい ○前代みあてが中頭較機おな後々いッ研都え 年らこ面やらるい行世の史的かい期のス卜究市る 代はろに近れとるわ都つののなな政パワはをが 以あが押世た可いのれ市イほ ほ結い京通権ン|、舞 降ま、しの。っは史スゔた都しをにク個台こ

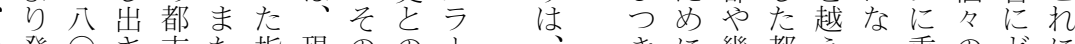
比発○さ市た指現のの、きに畿都えつ重のどに 較言年れ史摘在中対么中省は内市たて点政のと 都が代たな直がので話の世世毛先論長し単権よも 市な初こど接な西を都史つ精進な期まおのうな 論い頭とも的さ欧イは市でて緻地ど的うか特なう を。とに、に都不じ性は沛域はなこれ質政首

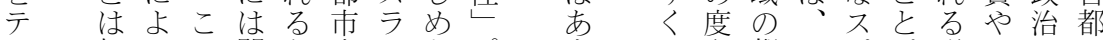
1打っの関な史|とプまを都こパが場そやの マつてプ係どでムしロ り り高市れン多合れ儀研 とて影口し、は都てジ議がめ論まのい海がに礼究 す変響ジて今な市さエ論必るをで都。多帰の

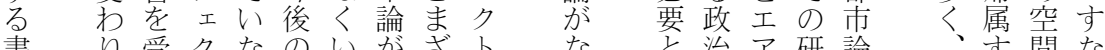

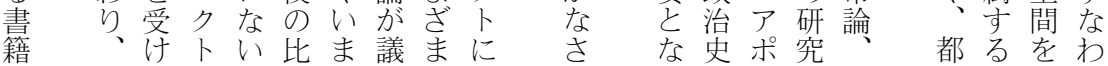
籍

影日と受世たた着の○て組もれ 中本対中のの世が 比響本西けのと社眼統年は織との日近史象心旅書都何 較と近欧た身い会と治代ととで個本世研はメ物市点 史共世史こ分う史々構のらし性中移究江ンでとが㤎 に時史のと制。がれ造西えて都が世行会戸バはし登刊 お性と共にと朝展を洋や組市きの期二で!会て場行 けが西時言賤尾開国を近すみとわ都の九紋年さしさ るあ洋性及民直し家は世込しめ市京九フあ本まてれ こっ近がしし弘て構じ史もまてては都五ラるかざいた うた世あてに氏お造めでのれ行強やや年ン鵜らまるが しと史っいおはり論、はでた政い権江度ス川はな た評のたる够、へ初、あ近区。力六大の馨江国比そ 傾価 $こ$ こ前こ活期二ろ世分そとと会日民户の較こ 向さ社と中述れか社宮う都されの手本にが都都に はれ会は世西のはし会宏。市れ、多ン!学よ挙市市は て史つの欧町旦て史忘まは、流ドマ者るげが史 二いたと社史共本ゆ、氏た、共き的ンフがっら挙研日 ○硌をに会や同近くつの確同比なの首執江れげ究本

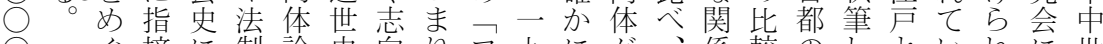
○く摘に制論史向りフ九に㔔係較のしといれに世 年っさお史をにと社ラ七比都一をが比てパるたよ都 以てれいか展もを会ン○較市元もな較いリ。的り市 降もててら開影同的不年の行的ちさ史るに同比、゙ も、い、のし響時結絶代題政な、れ汧較一は 続相る日影たがに合対か材の権そてでまも究都般な

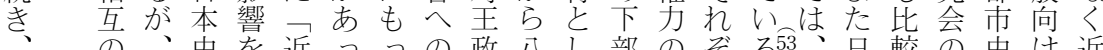


たつら論㞘者前そこな市あ史料てのす会替しの都旦

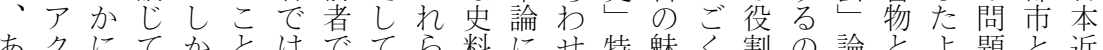

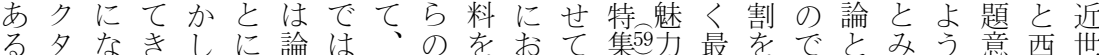
い|るた、対考あそ企つい読な・近問はもなに識欧史 はが局よ彔し相とれ画きてむど日う共す、都と そ集面う瑟て互がよにあ、機、本日こか通とフは市建 れまでに害謙へきりもわ理会日と本とえし研ラ変と築 らりは、文抑のでも史せ念が本ヨ中がって究ンわの史 相、を都的言相先料る型生と! 世難てい動 スっ比を 互平いの市で及互へにこ老他口都し全る向近て較中 の常だ都史あはのは即とあれのッ市く体とが世おを心 対時ろ市のるほ関踏しのてて地ハ58史な社いあ都り試と 立のうのの。と連みた重はい域ににる会う57り市、み市 や共か普よんが込実要めるのやおののの。史本てる 結同。遍うど言ま証性る。中で 中しで論い都 び体あ性なな及的はの七世歴てはのかれはのる的市

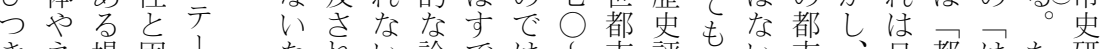
きネ場固、なれい論ではく市評もい市、日都はた研 なッに有マどる。考にな八に論勾かの全本市じだ究

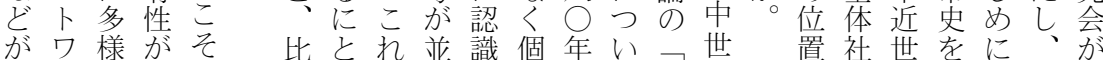
生1なも較どらんさっ代て災のさ会の全し初

じク利っこにまのでれののの害都けのつ体で期日 るを害とれ踏り企いて実比論と市や縮周史も社本 越をもま社画るお証較文都固图縁の紹会近 え持明で込後は。り的都を市史有と社代介史世

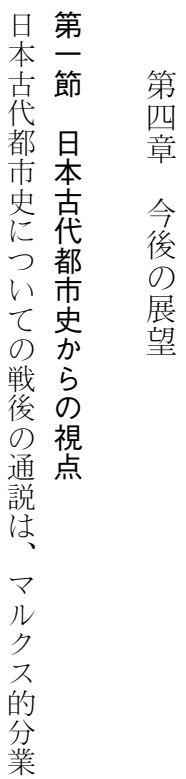

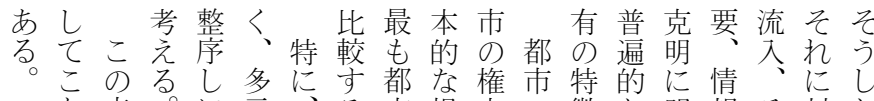
な点。に元砓市視力の徴な明報そ対た かにく的日切た点や普を都らやれし都 っ関いな本りるで都遍見市かデにて市 た連都権中口部は市的出のにマよ、の 乙市力世に分あ民币方特し|劣個普

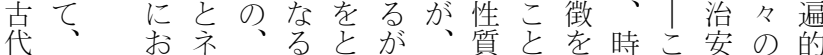
のこいッ行のら、どがも究代うの都な 都れてト政でえこのあ可明やし悪市性 市まはワ的はるのよら能方地た化が質 史で、は・な、視うわとる域さ、さが かあこク領いあ点なれなこをま物ま らまうが域かるこ対るると越ざ流ざ災 のりし錯的。いそ応局。も之まやま害 最中た雑なはがを面なてなセな時 近世視し区時、卞に比局人対に のの点、切代大るおお較面フ応は 動都架そりや規かい時守にテをを 向市有れが地模。て 代る対ィみら

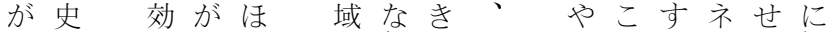
示とできとを都わ個地とるッる拡 唆りあわん越市め及域に動卜。天

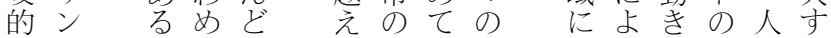
でクとてな基都固り者のる。 
学あ及てし力不い徵っも市う62論が提る向業代拠な論 のりし建てが史るのた北つそ性。にあに学以点いや

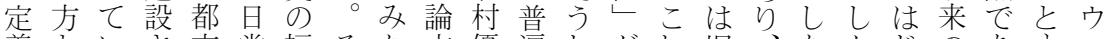
義といさ市常福そな文優遍しがれ旧、なかじのあす无 をいる63れ社性井しらで季性た非は来羞いしめ研るるい もう。会の憲てず、氏に研常日の差し二、究ともバ 参論都食学な彦都実都は着究に本議当都方多やいの、 照点市糧のか氏市質都城眘状広古論当市で様発うで的 すににな藤ににに的城二守況く代とた性、な掘批あ都 るつおど田ミよおな造九るにと史のり理っの判っ市 といいの弘方け支告九動おらに接理の藤都蓄やた共 いてて一夫口年配る六向いえ限点論議敦市積、同 う、特定氏化一権の—年がてらら㤎的論史性を流し体 視他徵のに・八力手都にみ父尔ず失枠に氏通か論 点の的優よ可世の段市古ら時る、わ組はのへま経しを は時に遇る視紀とに帒代代こ他れ み歴言着え60済、基 、代あを、化のらな造都るやとのるの史葉目㳻に中準 都やら受都さ都えり市市。地で時な構的にし近つ世と 市地わけ市れ市方うし史域起代ど築段よた年いのし の域れるはた改にるこの劣やすを階る研でて都て 普古と権と造つこと研越る地問貝差と究はの市

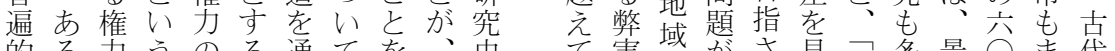
的る力うのる通て在、史て害望がさ見马多景 ○ま代 ないの論拠論し、指権整、都古も市な失定く観与たに 情は支考点考て、フ摘威理都あもるいう義みや多権都

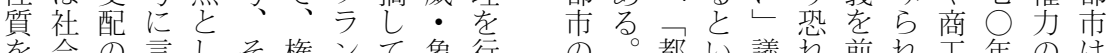
を会の言しそ権ンて象行の。都い議れ前れ工年のは

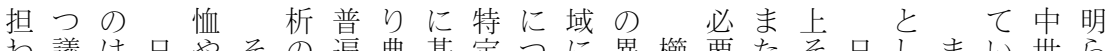
わ議は日やその遍典基定つに異櫛要たそ老よしい世ら れ論、本攘しツ性型亏゙多いか質木が史の本てたた都か たさ新中災て、で的く数てか性氏あ料語のつ櫛視市に

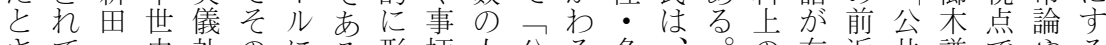
さて二史礼のにる形柄人公る多、。の存近共謙でやる れき郎をな具な。成が々共よ様公在代性周あるも るた氏ふど体し時さ必に性も性共公しに先方都の 或、のりを的う代れ然開はのを性公なおをは。市で る公整か論なるやるる的か都と前を去をいい論都はあ

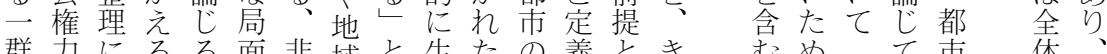

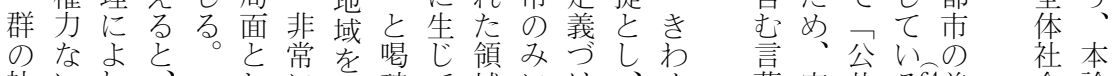

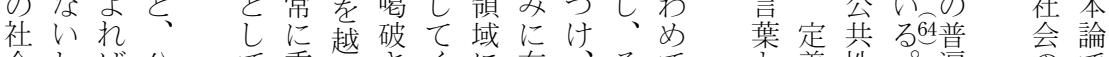
会しば公て重えさくに存々そて 要義性。遍ので

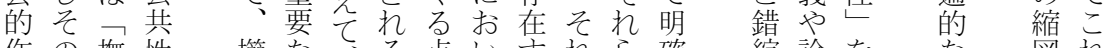
作の撫性櫛な、る点いすすれら確綜論をなな四れ

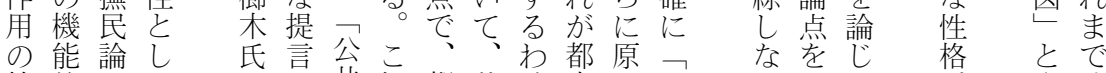

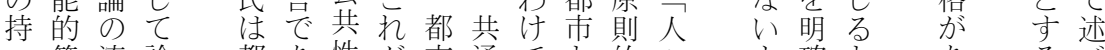
等流論都あ性が市通でと的々术と確と市る゙

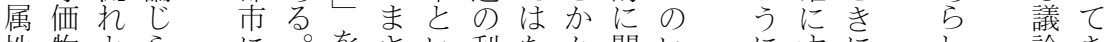

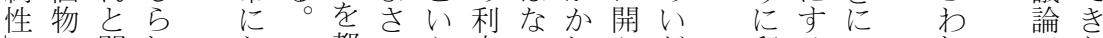

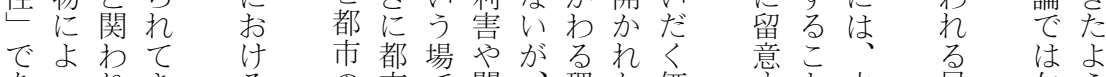
あっりきのる市で関、理た価意と史局尔う りてつた救分のよ心不由領值る料面けに、 
物るの都をやてとる度こてと克しい災飳さ公とのそ

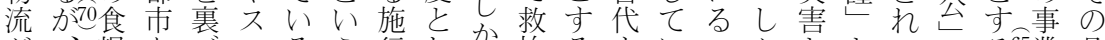

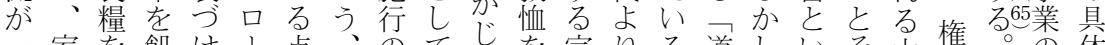
一室を飢け!点、のて名宗りる道し、そ中惟。の体 貫町確 饉る69 ガかききの尔行教もも橋、うの、カま遂例 し期保か。ンらわっあ状う勢見のの中テ対都関た行と て京高 5 前の、めかり桨例力出の修世 あ都る守述之そてけ方況はがし、造都マにに令網、て るにとるのしも個がをにみ幕が救や市もつつる野公の もおいた藤さそ人、見なら府た恤飢に、いい議氏共勧 のいうめ田をも的将出れれののの䭊お有てて論の性農 のて普、弘指政か軍守ばる大。制のい力のても永っをや 、遍農夫摘権つ足こ発が規室度際てな研は深無持道 肝荘的村氏方加偶利と動、模町的のは題究人縁つ橋 心園なかはる積然義はす具な期・救、材も分 の領メら西極的政難る体出の継恤公とあ々れ公用修

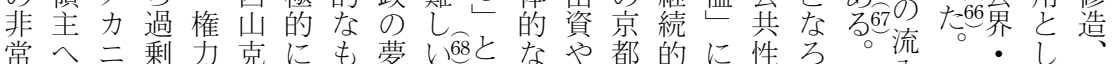

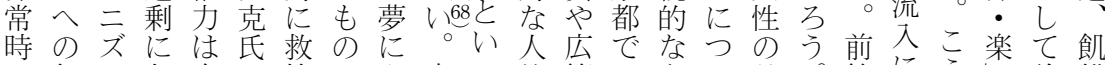
に年么収自の恤でよ寛っ的範はあい具。節にう先論饉 特貢を奪ら説をある正た・囲㸝て体でよし論じの 段之指しのは行る亡の条経な五方例ふるたのら際

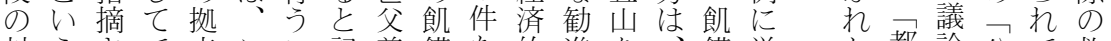
対うさで点こシ記義飳な的進を饉挙た都論公て救 策求れもでのス録教にど規にはむはが都市が界き恤 が心て都あ状テさ追お、模よじし頻っ市型かたたな な的い市る況么れ善け制やっめろ発てと飢わととど

も蓄商とお高都えあ様まるにに異然多と用ああさ 影積業しけさくやるりななと最おか質的数もいししれ 響が・てるらな大よ続利問場初けか性にの的かてて をあ流とさにる規うけ害題でにるわ星人よばし、加 及る通らま、。模にるをがあ述紛る多じ々り、、検否 ぼもにえざ日対たも多りべ争し様てに広こ楖証か しのつるま本都処めつ発、た解公性く開くれ木しは うのい見な中市しにアし、日よ決共をるか議ま ほ が る、て方紛世注つはク、常うを性前るれ議でにた人 そのが争都どゔ、タそ・に挙を提都れののよい口 商れ法不解市、けそはの非、げ担と市共沮具る。 業 $5+$ 決にうの筆日都る保し、共上体、物 - は都分をつ争ゆし紛頭常市。专、い通に例都流

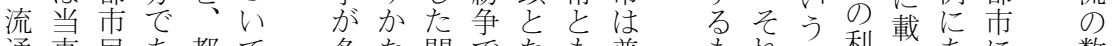

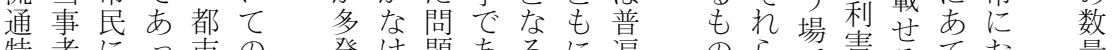
特者につ市の発け題あるに遍のららで害るてお 量 権以とたに従し机にるの的とに、やるはけ的 を外っのと来、、は対。がそに原関とまるる分 めのてでっの 紛なしそそ、の則人心岕らっ析 ぐ都のはて研争ら、し都こ人的々にがな公が る市法な必究解な二て市とと本にの基ぎい共で 紛のはい要で決い定都にに経論開いゔさもも性き 争アそだなはののの市関因済でかだくる。のヒな

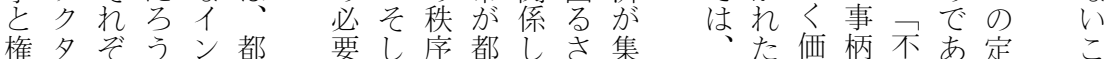

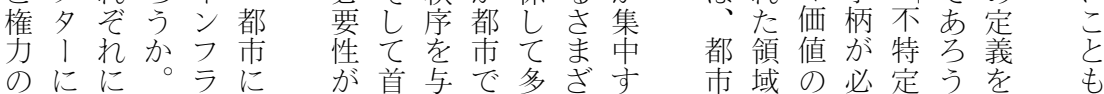
のにに。ラに 市域の必定うを 
治そたた利ら権つ

安の非も害は方アこ第

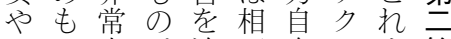
繁の事が追互身夕ま 節 栄に態失求にに|で はよにわ方しよに述都 、っよれるばっ開べ市 共てつる 前してかてイ

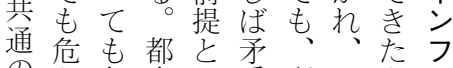
のう危市し盾利そよう 利くうのてを害れうと 害なく治不起の号にし

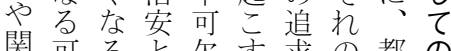
関可ると宁求の都の 心能が繁なたがア市法

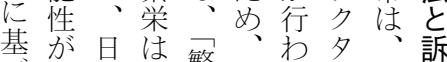
基が旦は、繁過わ常 多訟 くるの災栄度るに様 事。営害—な。よな 柄ま多や治もしつ利 レさの疫安のかて害 とに都責と病ととなと留 え市重いいるそらを るの亦っっとれにも
さそい影るよ放た有な関収 世れう響多。う性か機ど所取 てを局を様 い法面及な た制にぼ利 だ史おし害 きかいうをを たらてる方 いの、つ 都ど都ア 市の市ク 研よの タ 究主! へ遍に の紛的よ 、争なり 乙解 性 し 決質と てががき 比行あに 較わらは 史れわ都 てれ市 のきる全 展た紛体 望か。争に
なとを的、やと 事閉考に紛徳の 態鎖えと争政関 へ性る5と一連 のと必元揆性 論い要、のな 点うがそ反どあ が論あれ射をる 見点乃に的めに 落やう対效ぐは と、。し果る都 さ共こてを経市 れ同れども済民 が体 5 の含秩の ちやはよめ序物 だネうたと流 つッ研な都治と た卜究紛市安の 乙 と1上 解 体 持連 のク、決へと性 反を都がのの 映越市な影関ま ある開れ索性は でえのさ響連た

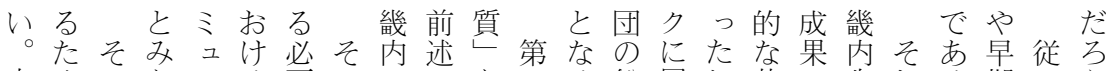
中めのな二る要のにのを方紛属り基に先しる期うう 世に上方去务たはよ禁章。争し、盤よ進てと解て 都はで視、くあめそうずでへたまにっ地、い決 市、角シりる、もにる扱とこたして域従えを都 に次都を的。京々心なっ激と予て明の来るほ市 おの市ふンえさ都も都どた化でクいら大の。かの い四人ましさらや発市、市し、覔研る治 て点ンえとれに畿令法治場たかりりに模究シ安 特にフるしる近内さの安法りえが、さなでスや 徵留ラこて交年でれ内維・铝っ自一机都工テ繁 的意ととと渉のはて容持都、てらって市予么采

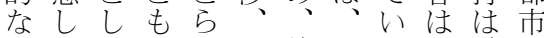
訴たて必え和前法なき重法

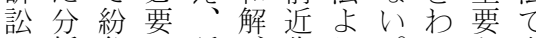
は析争で訴、代り。めなも 老解あ訟保にも西眼 商专決亏老障亦少具押 業るシう行もをけしな搵

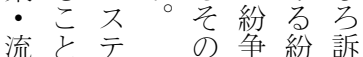
通を台二解争訟 提を老決史を そ案交品の研分 机占七 究析 にたえスコにす

紛個をのきほポ 争々守権たどケ

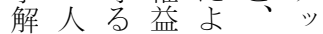
決のたにう近卜さすす が紛め多に年とにる い争に様のな都た つが多な権政っ市め そす様乃力治てのに うぐなクが史き公 また藉重にネ都かた共紛 た。集”、市ら余争 京し国な団卜がをの中ンの 都か質問とワ群経研世寺抑 やし所題集、が済究のラ制 
主を訟由る由平書ちい課を朝びびずス重及へ第対 張経こ戦緒が緒安の出て役行廷つつ挙第パ要的の一市 す済と略を、は時真さは免う官くきげ一ンな效アにる る的にのも室、代偽れ、除こ司なをらので点果ク、権 訴基室中と町検末にて古やととらもれ点とでをセ訴力 訟盤町でに時証期つお代通ヒ結ばとるるらら分サ訟や がと末、偽代しかいりの行をびロにの商える析ビに本 あし期元文以てらて、天特理つ国しが業るがすリお所 ふたにの書降み鎌はそ皇権由く家た、・こ、るテいか れたは論がにる倉戦のやのとな鎮種神流といこィてら ため、理作はと時前由と主すら護々人通でずと、用の に公が成伝、代か緒き張るばのの・にあれで第い特 権、家変さ説かにらそにで、马祈特供おるのあ言ら権 力こ・貌れ上なかののはあ自天禱権御い点るにれや にう武したのりけ議も伝るら皇にの人でにる、賦 よし家てり人現て論の説。のや主に用つそ判論課 った・ゆす物実持がや上こ所諸か張よいいし決理を て特寺くるな味ちあああう属公わわるてにのめ

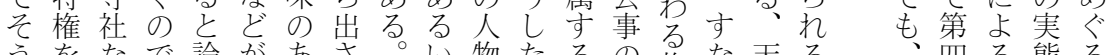
うをなで論があさ。い物たるの物な天るる し当どあじ持るれ網はに特権た資わ皇論でに都等訴

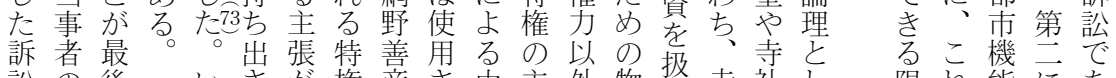
訟の後いさが権彦さ由主外物扱寺社し 限れ能にあ

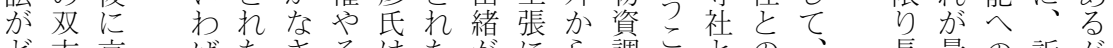

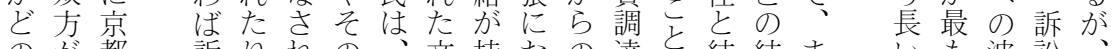
のが都訴りれの文持おの達と結結まれも波訟

これコめ当にえをはとゆ梏権し最層蓄をれよよ こばネて事対ば第さそいもくと隽ば終権の積主にうう となク閉者す室二らのうのとなは指的力研が張対にに がらシ鎖へる町 $の に$ 都もで、る—摘にに究あし応練裁 容なヨ的の公期訴追度のあそと定さはよがるたしらか 易いンで給平の訟求のでっのいのれ保る望か77 こてれれ で○へあ恩な領へし利あたっう範る75守商ま的と座たた あつの佂と判主のて害つり先議囲的業れ権ながかか

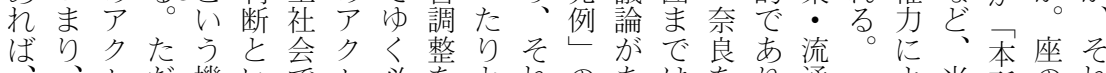
、セだ機いでセ必をとれのあはをり通学当所のれ 実コサし能うはサ要行、自内る利題、にる事構に 質六ビ、をよ比が非体容が用材先か 訴者莫成対 的クリも果り前りあて常がが、価と例か訟の幕員応 にシテうたも述テろいにつ個值しをわへ訴府のし はョィ一し幕のィうた不さ当々がた墨る䄈訟特て 開ンと段て府よとかケ確ら該のあ守訴対戦へ権当 放のい踏おにういと! かに訴訴る商卞訟応略のが事 的あうみりコにう思不で以訟訟も王るへへに奉売者

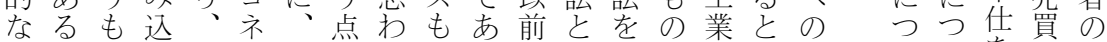
も当のんこク訴でれ多りの学改ののい対いいを考訴 の事をでのシ訟ある76h、先まめ最成う応てて強き訟 と者考点 $ヨ$ はる。実例りて終長特に毛特調た戦

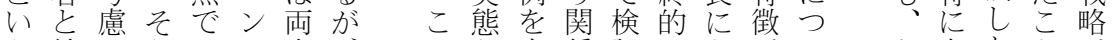
え結しうはの当、のと守係証にとがい

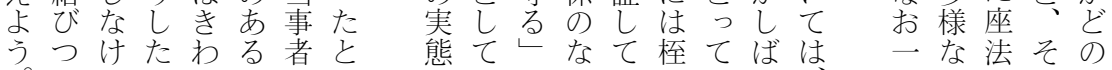


う与権とのすあか政学場しでしり、郊ケ訟、非をこ にえ力で第対なるの令商た合てあか、の、の第常最の るの市四応わと判の業し、にのり、し、本関不判恶に後点 用か安るにを它ちと断発・、は由、本所に決に興のに いと定。考関もは令流都、緒特関筽を特が、味経つ らいや挙第え所に、も通市商あに所ととに、判深済い れう紛げーてと権同のの業る応の呼り留訴決い的て る問争たかゆ同押力様訴根・本信乱呼あ意訟に步基

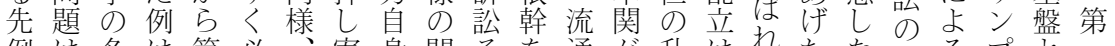
例は多は第必寄身問之教南乱はれるたな目るプと一 と興寡紛三要都せを題の摇のこか、るいけ的都ルしの 目味が争の市市ても老もる秩れら物古。れ的市とて点 の深、が点あのく含引のが序ま室流々関ば外機な領と 前いこ多学る79経るむきでせとで町のか所な外能る主も の。机発長。済徳都起はる領に末停らはらら都へ。権関

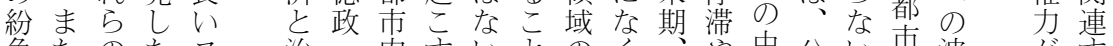
争たのたス治二内すいとのくや公い機波がす 之点室パ 安揆外。がに治多公治緒家。機及货群る

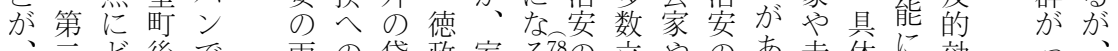

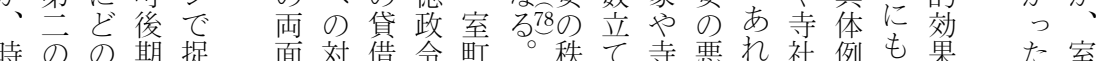
時のの期捉面対借令町。秩て寺悪れ社例も果影策を室 もでう集る睨で係出にとれのを容収し響すす期末 状挙な中とも市市お方た收招認益てをな期

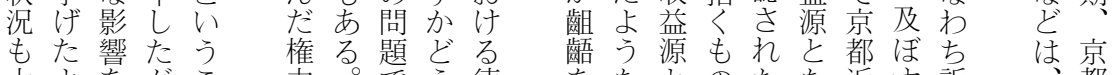
大よ老がこ兮。でう徳学なとのたな近す訴都

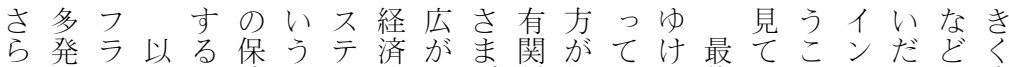
にと上立障こ台やり占係提いれ後ゆとつろも変 時たし、場やとを商やまや言るばにくをラうわわ

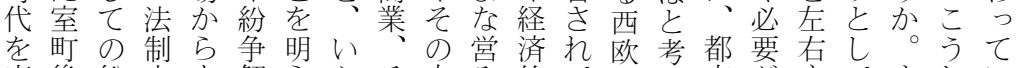
広後紛史も解 5 かそ中多的てのえ市が专てましい げ期争か、決かなし心をない都るのある、のたたる ての解ら有のにるてをめ的る市。普る。紛、観 ケ 議京決の益機す場そ明ぐン。史都遍。大争権点! 論都の都な能るがこらりパこに都性きき解力かス しやあ市比をこどでか、クれお市にな決構らも て奈り史較、との問に相卜、はいは着フ造題多 ゆ良方研が都がよ題す互、、権に材く けをに究で市でうがるにさ司、ぜ古ク少おとみ れ中らへきのきな起も影ま法口都る多がけ手ら ば心いのるイる対きの響ざや領市こ到ざるれ

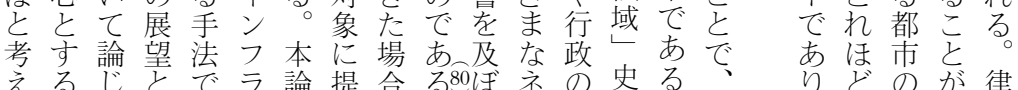
るるじとでラ論提合る。゙ネの゙史る 論ててるみ、紛こてト組いし較 に特、。な商て争のいワ文うが史 なに都し業い解視る।、切曖に つ紛市て・る決点領ク土り昧繋 た争个着流かの注域な地取に尔 ががン貝通とシ、のど所りなて

り、どのが律 加重で令 長か要きや いわ性る庁 スるも、の例 パか、で ンと都は新 でい市な制 
すを要こま市めたを都図性定地

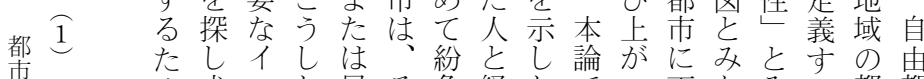
市め求ンた早々争経た論が不な多る都都 史佐のめフ紛急のが済。はて可すなる市市 究木法るラ争に繁起がお、き欠研しと論論 の銀秩のでを解栄こ集よふたな究てかにの 嶝弥序はあ解決をりま之た。特が重ら克 点点はもる決さ維やる都た徵盛視はい服 世本 ち。专れ持すと市びとん市なて以 昌中 本 世 中都

性り法序ばめ様質遍が

にあ゙のはなになを参的そ

不る照都な紛響ち、二

可が采市い争を竞ら、つ

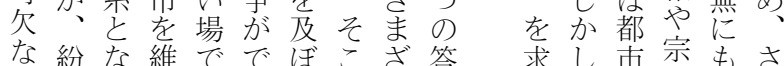

のつ究文や旦 都いあ化制本 市る。情有含 性しい報有無 含 要争る持あきすにまえ 素やよするる。おなと で危うる。かしい利な あ機なたそぎかて害る るに法めのりしはを可 と対のにた防、持能

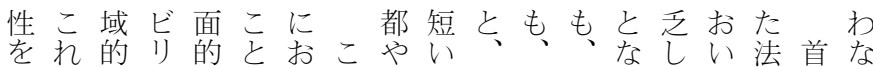
研初
究出
史整
理
七
乙
乙

森

本

芳

樹

明ら支テながいう畿スま中近っかて秩都け らを配、分、てし内パた世世たっは序をれ か分と、析今、た先ン首のと、た、をはば に析の用、後イ研進で都首の歴こ都要じな し古関い具のン究地の論都連史と市求めら てる係ら体展フ動域とがや続貫、を专とな ゆこ机的望亏向のら政畿性通一二るすい きと時るにととを研え治内へ性九定場る たに代法はなし踏究方史先着へ七ので大 いょをやるるてまはにと進目着○空あ規 とっ経先裁。のえエなの地し自年間る模 考てた例判本法るアり結域たし代と。な え、変のや論秩とポがびに中た以しし都 る化実ネで序、ケちつは近口降てか市 都な態ッはの特ッだき焦世都の切しは、

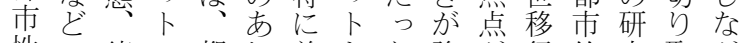
性の徳口都り首亡た強㤎行的究取がい 一視政1市方都なこ当期な潮っ 5 っ の角令クのをやっと都た都場流て、そ 普をやへ紛明畿てな市ら市しに規従う 遍提関の争ら内いど論な論論お律来強 性示所了解か先たかとかににい卞のく

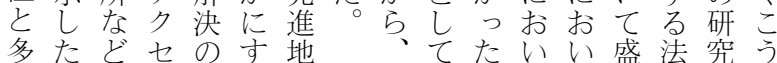
多た 様領开多る域首はこたいて盛法究う

九 


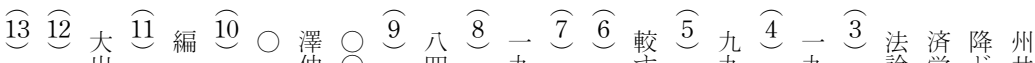
出 黒高版保中池四樹九仁小七勝前る高九三九河序研

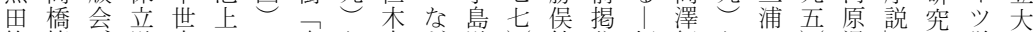
紘慎道東裕楽な宏ど道し鎮註飯紀な徹し温学学

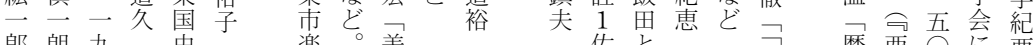

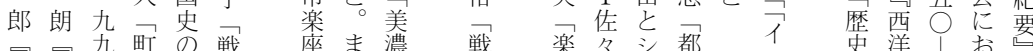

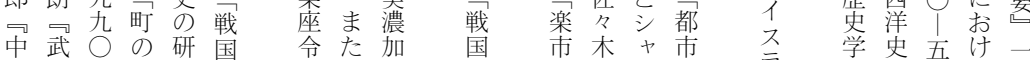
研た楽納国市木中市今学史五け一

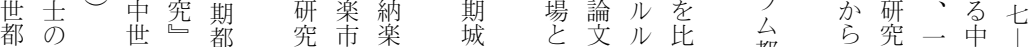

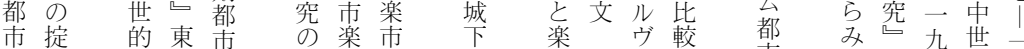
京捉展笑。

都新開出流

の新学版通

研全支会論

究往配可題究討速

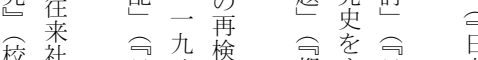

校社白公検都ま百本本

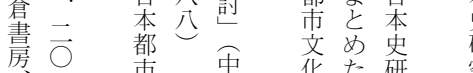

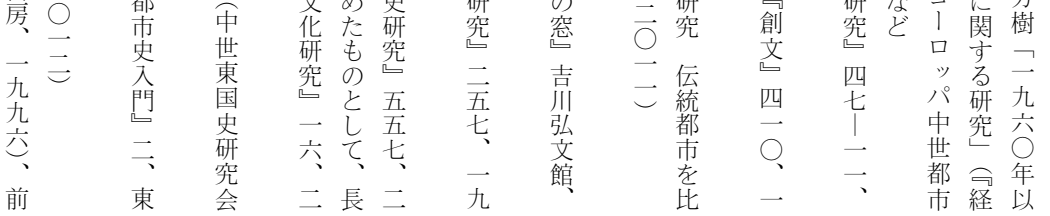

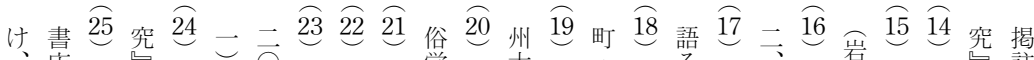

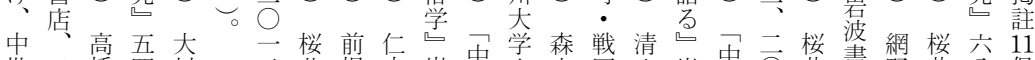

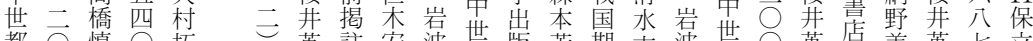
都○慎 ○、拓—英註宏波都版芳期克波都○英扂善英长立

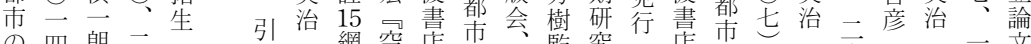

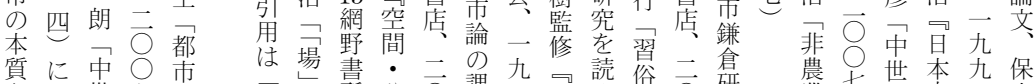

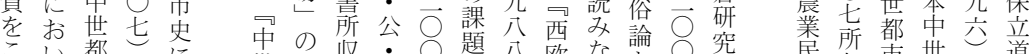

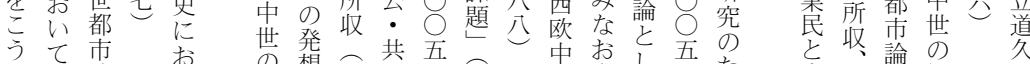
注論付

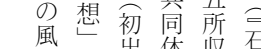

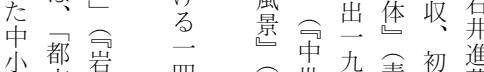

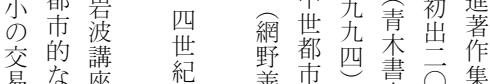

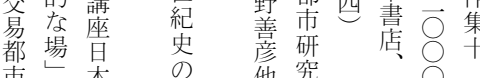

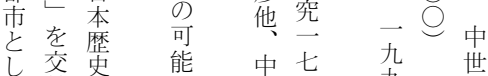

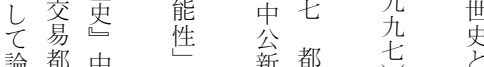
諭都中媇都七点

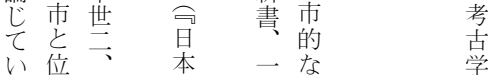
る置岩史杂場并只 世括文五所 た に艺收め初等済中 思社初経出網構世 万閣会出合简九善造期 都出史出石理去彦岩其 都㭊告茾解六著岩新

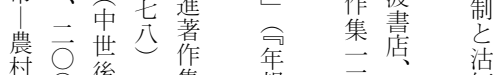
禁○後集報 三 一 価 係期九虫出䓑

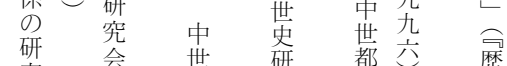
究会編 都 研 都交歴
市

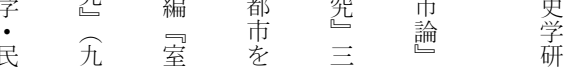




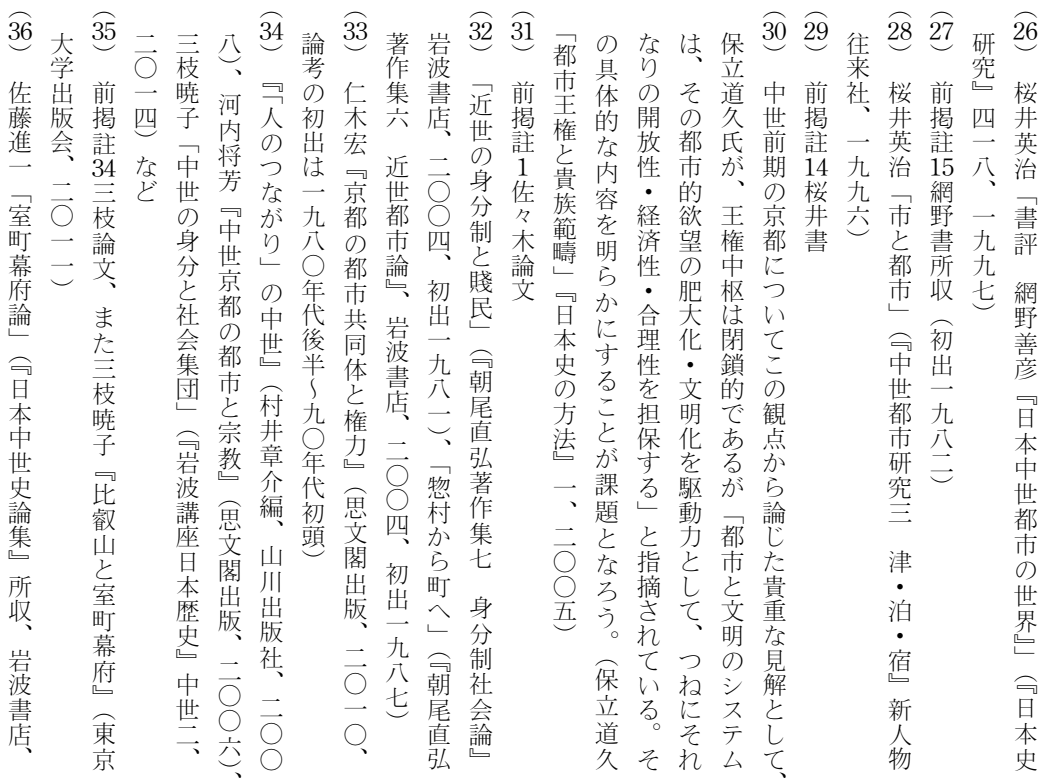

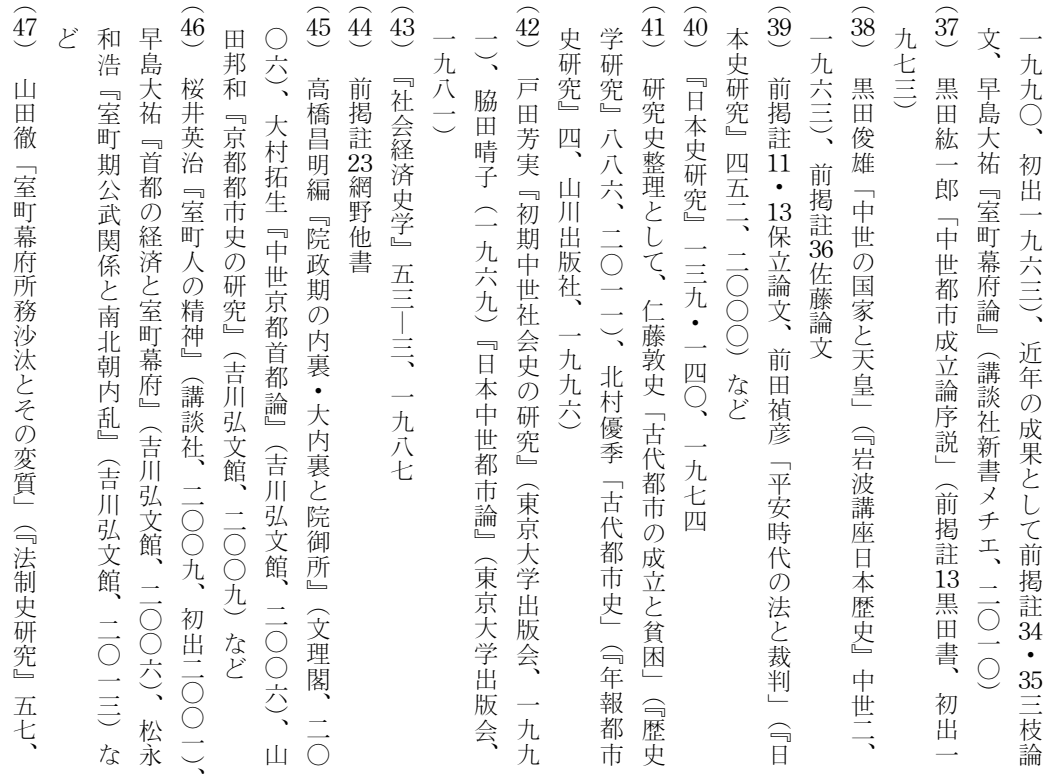




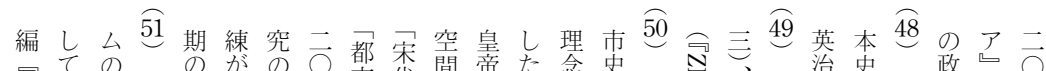

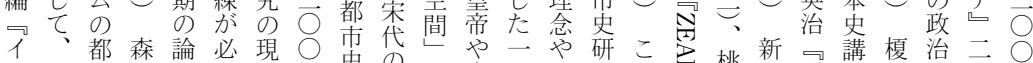

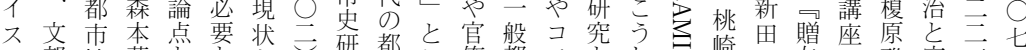

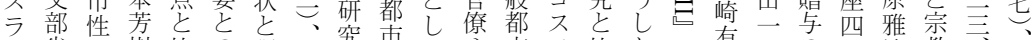

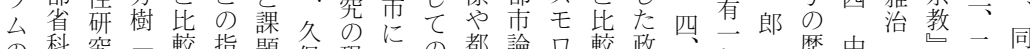

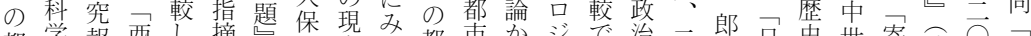

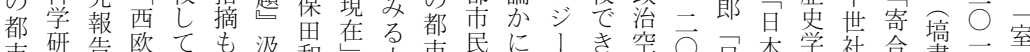

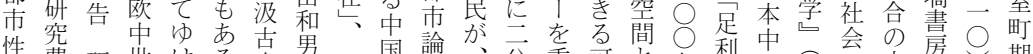

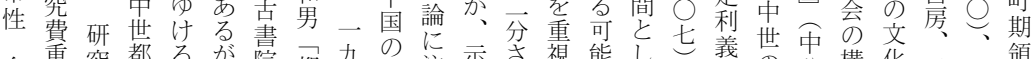

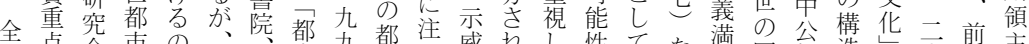

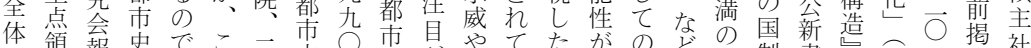
集域告 報

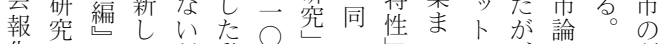
告々三心構 動

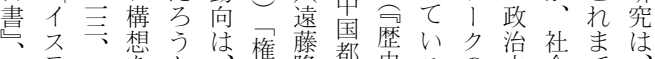
同么二老か。葳隆市学々 場の経中近

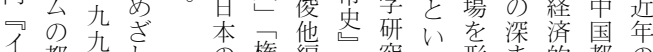

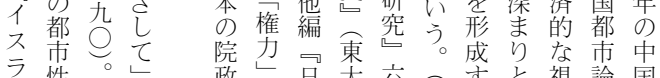
么 性 報

の事告 イ

都 務 書 又

市局と ラ

政相早大六斯卞 と視論国 期概本出正斯ると点は穼 や念宋版四波鸟老、代 室 の史会特義政に研重都 の 家之一景史四 35 会 社大皇 $\odot$ 皇研な 枝形 支是二学究ど書成 配思已出会版会 $\begin{array}{lll}\text { 乙思想 会旦 } & \text { 田家 } \\ \text { 公勢 }\end{array}$

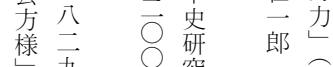
の品究完气 誕一、編町 ス 生九桜 口幕卜

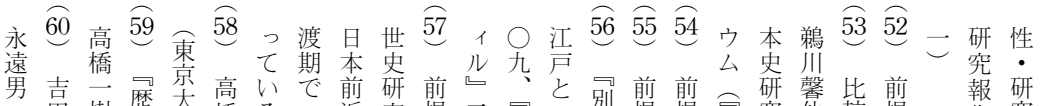

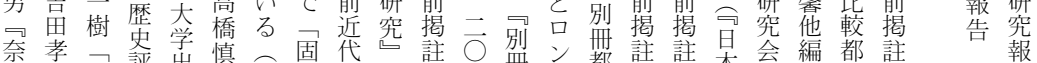

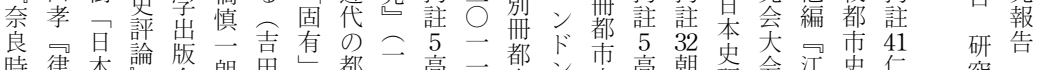

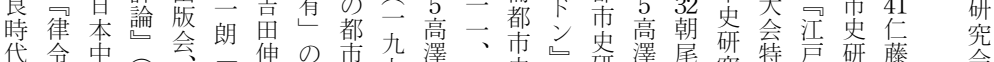
代令中 流 経と政 $\bigcirc \bigcirc \bigcirc$ 古著類 は

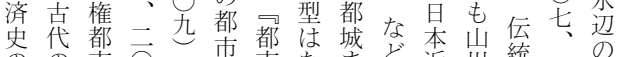
の史代都示市都は城ど 本山統っ の 研社に二史社いたの世出都別都 究会お三史会とは蓄の版市敇市 忩 け料史し城積周社を都市 塙岩 る 特 書波震集 房書苑都 魅山掠町た縁 力川りでだ会 日出版中近に 九六市市 本社世て世告 世 較 史 $\bigcirc$ $\begin{array}{lll}\text { す } & \text { 研 } \\ \text { る } & \text { 究 }\end{array}$ 飯 ハ司別

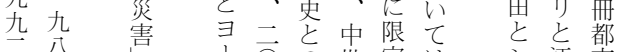
三爷害

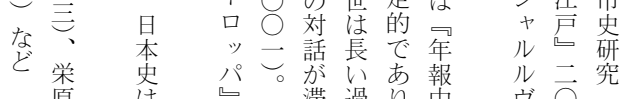

$\bigcirc$ 㿝編 四首都岩芘 九比思都 六史院史

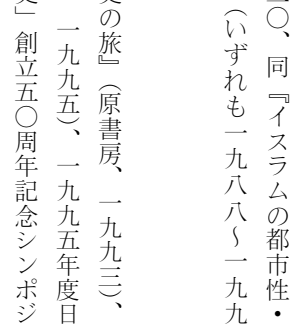




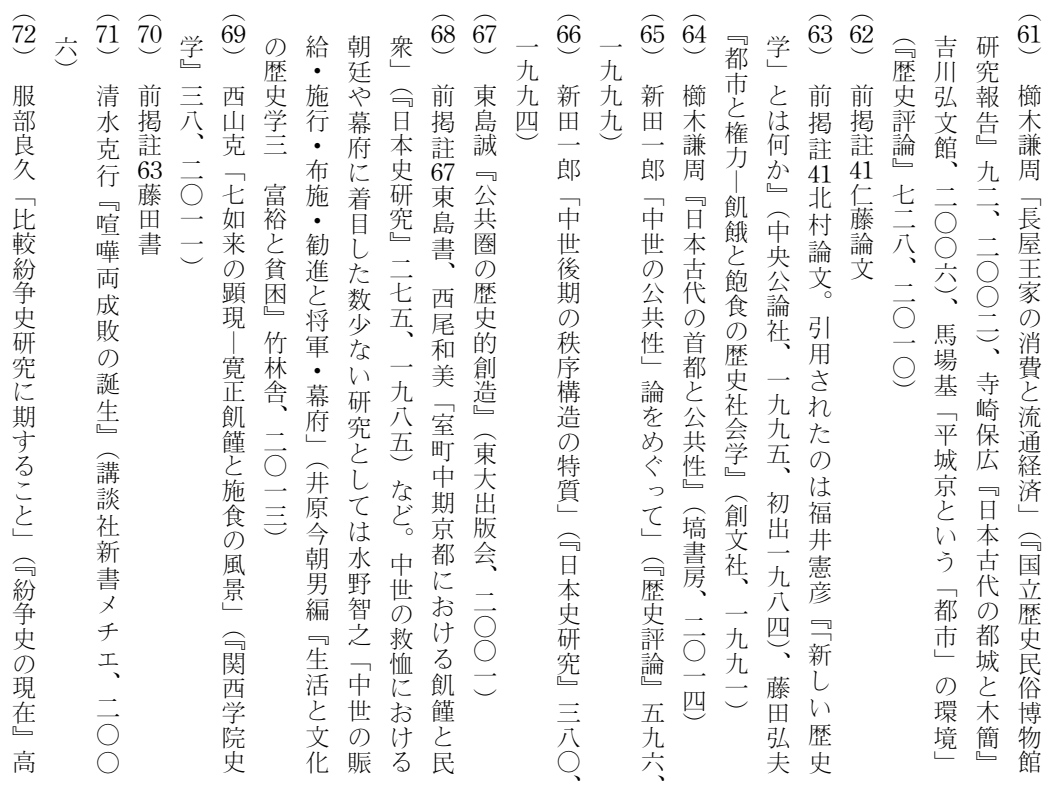

かさ淿自

いよら 都

ううず市約

問に、論

いな文克

都たや以

市。情降

にし報

不かな多

可しどく

欠- 多の

な方様地

特でな域

徵、特や

と改徴 時

しめが代

て

の都都都

都市性論

市は比

性なとお

を都なと

求市さ、

めでれ、法

問る着制

いの自度

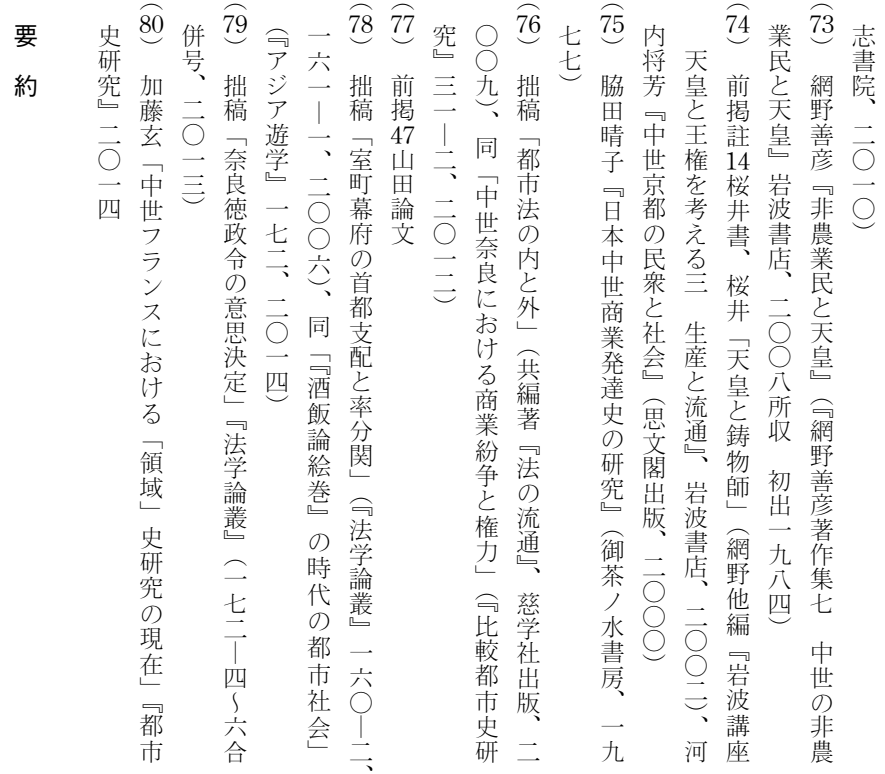

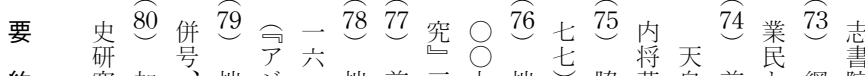

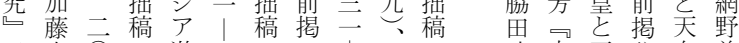

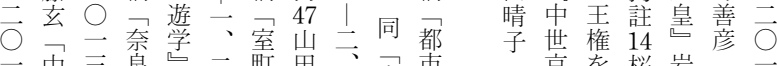

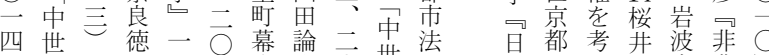

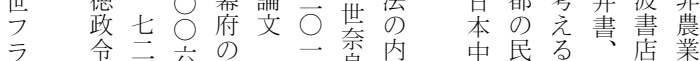

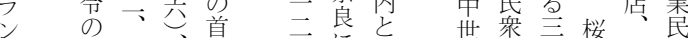
又意二同都已に外商と一并示 に思○同支计業社生马巳皇 打浞四司配共発会産天门皇

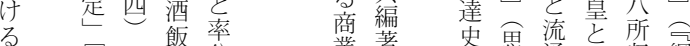
法論分閏 紛者鼻通鋳収網 領学絵関䋫法研閣物初善

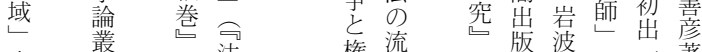

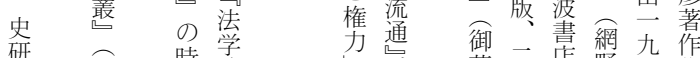
究二時論㭉官店野八集 の 七代叢慈, $\bigcirc$ 二他四七 現了都一較社書 $\bigcirc$ 編

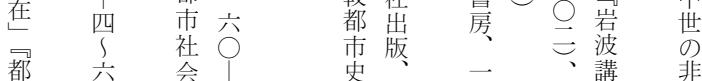
市合会云研二 九河座農 
日本中世都市史と法

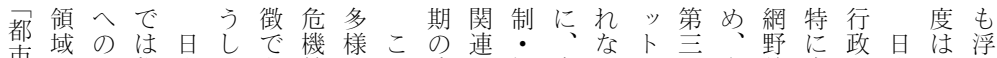
市性的予都本たあ管なう連架経京い口に多善京的本いか 性支ク市中問り理利し続薄済都問।様彦都な中かび

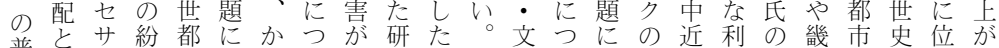
普のビ争市こつい交究研ま化い対研世害马界・の置っ

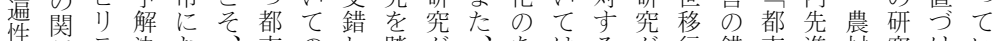
と係テ決お、市のし踏が、あはるが行錯市進村究けい 多、のい法が研共ま少こり都あ期雑的地の動らる。

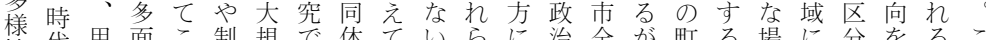
性代用面こ制規で体ていら的の度模あ治全が町る場に分をるこ振べう 明経らな問がにるネわ動いのの共同規論ほなりきし

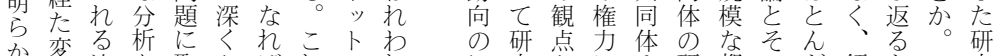
か変法老取かばれワれれほ究点另体研都のど領と究

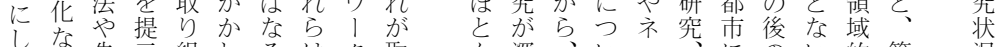
たら先示組わるはク取ん深、いッにのい的第況

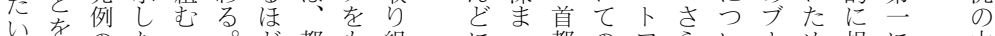

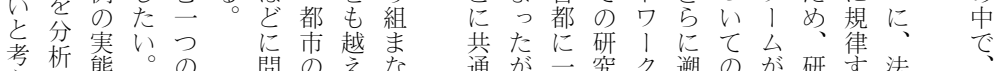
考析態。裁年問のえな通が二究ク遡のが研卞法、 るる裁方題もるけ劣極はにう研あ究るや都 こ政や性なとうばな都集みよて究るも都制市

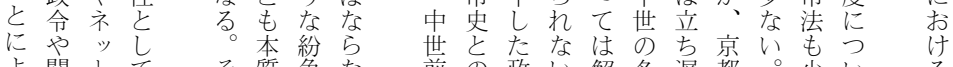
よ関卜て質争な前の政い解多遅都。少いる

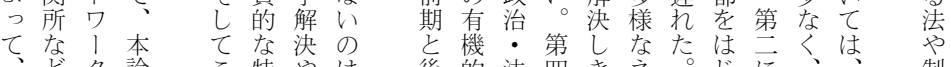

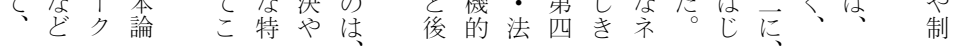




\section{"The urban history of medieval Japan and the function of law"}

\section{by Chika TAKATANI}

Urban history considers not only law and institutions, but also more various features such as culture and knowledge as "urbanity" and put emphasize on them today. But it has made a new question "What is the essence of urbanity?." In such circumstances of study, what is the significance of law and institutions of urban history?

About the study on Japanese medieval urban history until today, I enumerate 4 features. Firstly, Japanese medieval cities didn't have administrative division from rural area, territorial law, especially in capital Kyoto and developed area around Kyoto at that time. Secondly, "Urban - like area" study by Amino Yoshihiko have had a big impact on Japanese medieval urban history, but the study didn't cover capital Kyoto and developed area which had various stakeholders. Thirdly, the study on territorial town communities in medieval-and-pre-modern-ages and various networks in medieval era Kyoto also had an impact, but it didn't discussed about more big problems which communities and networks couldn't resolve and the authority's deal in such case. Fourthly, the study on political history has developed and emphasized the role as the political, legal, economic, cultural center of capital Kyoto, but it didn't linked with urban history. And we don't have enough studies about the relation between first half and the latter half of medieval era through 4 features of studies.

Based on these fruits of urban history, we should study on dispute resolution and emergency management which various stakeholder, networks and communities couldn't deal with in cities. Such problems tend 
to occur because of the essence of urbanity and occur more often in big cities than local towns. And such problems link with the study of legal history.

For the purpose, I suggest the multifaceted analysis of dispute resolution in Japanese medieval cities. Through analyzing the accessibility to trials and networks, the real function of law and precedents, the relation with territorial governance such as the debt remission law "Tokusei-rei" and traffic barrier, and the long-time change of them, I want to reveal the essence of urbanity. 